\title{
Operational Strategies for Cost Effective Mass Cultivation of Halophilic Microalgal Strain Pseudanabaena limnetica in 1000 L Flat Panel Photobioreactor
}

Magar Chaitanya Sampat ${ }^{1}$ and Deodhar Manjushri Arun ${ }^{2^{*}}$

${ }^{1}$ Department of Biotechnology, KET's V.G. Vaze College of Arts, Science and Commerce, Mumbai, Maharashtra, India

${ }^{2}$ Department of Botany, KET's V.G. Vaze College of Arts, Science and Commerce, Mumbai, Maharashtra, India

\begin{abstract}
Worldwide microalgae have been known for their wide industrial applications since many centuries, but large scale cultivation of algae in photo bioreactors is still having many constraints with regards to construction cost, system dimensions, culture sustainability and productivity. Algal feedstock production is impended by failure of translation of laboratory studies to field scale ups. The present research work deals with the construction of the low cost flat panel photobioreactor system and optimization of operational strategies. The microalgal strain selected for mass cultivation is an indigenous halophilic Pseudanabaena limnetica species, which sustains at high temperature and light intensity of summer season and it could be grown in marine water. Therefore, actual seawater has been utilized for cost effective biomass production. Flat panel photobioreactor was scaled up from $8 \mathrm{~L}$ to $250 \mathrm{~L}$. Three airlift panels with dimensions of: length $\times$ height $\times$ breadth as $25 \mathrm{~cm} \times 38 \mathrm{~cm} \times 10 \mathrm{~cm}(8 \mathrm{~L}), 50 \mathrm{~cm} \times 70 \mathrm{~cm}$ $\times 20 \mathrm{~cm}(60 \mathrm{~L})$ and $100 \mathrm{~cm} \times 110 \mathrm{~cm} \times 28 \mathrm{~cm}(250 \mathrm{~L})$ have been developed. The optimization of air flow rate and sparger pore size was conducted. Physical parameters like, Sparger velocity $(\mathrm{v}) \mathrm{m} / \mathrm{s}$ along with change in Reynolds number $(R e)$, superficial velocity of gas (Usg), gas holdup $(\varepsilon)$ were studied for their efficiency to support algal growth. Also optimization of other important parameters like light intensity, inoculum size was carried out in laboratory condition and correlated with the biomass production. After optimization each PBR was operated in outdoor conditions. Electric power consumption, its cost estimation, total biomass productivity and operational feasibility of the developed photobioreactor system were also discussed. After optimization of operational strategy for working of photo bioreactors in laboratory and outdoor conditions, $60 \mathrm{~L}$ flat panel photobioreactor was found to be most suitable for large scale cultivation of $P$. Limnetica. Therefore attempts have been initiated to construct and assemble the $1000 \mathrm{~L}$ photobioreactor system.
\end{abstract}

Keywords: Halophilic; Marine water; Airlift; Physical parameters; Biomass productivity; Cost estimation

\section{Introduction}

Microalgae are group of photosynthetic organisms which can grow in diverse environmental conditions. They have tremendous potentials which can be implemented in numerous industrial applications. Microalgal cultivation has two main goals in recent years. The one is to produce algal feed stock for next generation biofuel and another purpose is to utilize the biomass for the production of value added products for human food, animal feed, cosmetics and pharmaceuticals [1-4]. To achieve these goals, the technology for continuous and cost effective biomass generation has to be derived. And hence, the priority focus of scientific community in algae mass cultivation is on cultivation systems, which may be either, open (raceway ponds) or closed (photo bioreactors) system. Construction cost wise raceway ponds are cheaper but low biomass productivity and contamination issues are major constrains. To avoid these issues scientist are focusing on the closed Photobioreactor (PBR) systems [5,6]. Amongst all the PBRs developed till date the major constraints are related to their design, operational feasibility, biomass productivity, and overall high construction and operation cost.

In the present communication the flat panel PBR was scaled up from $8 \mathrm{~L}$ to $60 \mathrm{~L}$ and $60 \mathrm{~L} 250 \mathrm{~L}$ for the cultivation of indigenous halophilic microalgal strain Pseudanabaena limnetica. While developing this non-sterile but fair biomass compliant PBR system many physical parameters were taken into the consideration. The parameters like, air flow rate of pneumatic agitation and sparger design (dimensions and pore size) were critically judged to avoid damage to the growing culture.
Other important parameters include artificial light exposure which has great importance in cultivation of photosynthetic organism. The growing culture requires optimum light exposure which facilitates biochemical conversions in its photosynthesis procedure. As the dimensions of the culture system changes the requirement of the light exposure changes, which allow the light to penetrate or to reach optimally at each growing microalgal cell [7]. Along with the optimization of light conditions necessary suitable initial population density or inoculums size is also important. Chen et al. [8] has explained an inappropriate inoculums density with that of the exposed light intensity leads to the failure of mass cultivation system. If high light is given to the less inoculum size the culture dies off due to the photo inhibition and scanty growth is observed in highly dense culture where evenly light distribution is limited. After optimization of all working strategies for PBR, the costing comes into the picture. This decides the economic worthiness of the developed PBR system and if could to be utilized for industrial mass cultivation.

"Corresponding author: Deodhar MA, Department of Botany, KET's V. G. Vaze College of Arts, Science and Commerce, Mumbai, Maharashtra, India, Tel: +919870176411; E-mail: drmadeodhar@gmail.com

Received September 20, 2018; Accepted September 27, 2018; Published October 06, 2018

Citation: Magar CS, Deodhar MA (2018) Operational Strategies for Cost Effective Mass Cultivation of Halophilic Microalgal Strain Pseudanabaena limnetica in 1000 L Flat Panel Photobioreactor. J Pet Environ Biotechnol 9: 380. doi: 10.4172/2157 7463.1000380

Copyright: ( 2018 Magar CS, et al. This is an open-access article distributed under the terms of the Creative Commons Attribution License, which permits unrestricted use, distribution, and reproduction in any medium, provided the original author and source are credited. 


\section{Materials and Methods}

\section{Microalgal strain}

Microalgal strain selected was Pseudanabaena limnetica (Lemm) Komarek, which is an indigenous halophilic strain isolated from salt pans of Mumbai suburban region. It sustains at high salinity up to 3.5\% $(35,000 \mathrm{ppm})$, and at high temperature and light condition of tropic environment which reaches to $45^{\circ} \mathrm{C}$ and 85,000 Lux respectively in summer season. This strain thrives in alkaline conditions of seawater and sequesters anthropogenic $\mathrm{CO}_{2}$.

\section{Culture medium}

Modified seawater BG11 medium (MSWBG11) was formulated from the BG11 medium [9] as tabulated in Table 1. The chemicals used were obtained from Loba Chemie Pvt. Ltd.

\section{Photobioreactor design}

Three flat panel photobioreactors were constructed from diamond polished extra clear aquarium glass of varying thickness. The dimensions of the each PBR system (Figure 1) as length $\times$ height $\times$ breadth were as follows.

1. $8 \mathrm{~L} \mathrm{PBR}-25 \mathrm{~cm} \times 38 \mathrm{~cm} \times 10 \mathrm{~cm}$, glass material used was of 4 mm thickness.

2. $60 \mathrm{~L} \mathrm{PBR}-50 \mathrm{~cm} \times 70 \mathrm{~cm} \times 20 \mathrm{~cm}$, glass material used was of 6 $\mathrm{mm}$ thickness.

3. $250 \mathrm{~L} \mathrm{PBR}-100 \mathrm{~cm} \times 110 \mathrm{~cm} \times 28 \mathrm{~cm}$, glass material used was of $12 \mathrm{~mm}$ thickness.

For pneumatic agitation PVC plastic pipe $(12 \mathrm{~mm}$ internal diameter, $2 \mathrm{~mm}$ thickness) material made, L shaped spargers were constructed as explained in the further context of sparger design. Each system contains pair of such spargers, placed discretely at the bottom in opposite directions.

\section{Culture conditions}

The mother stock of $P$. limnetica was always maintained in sterile Modified sea water based BG11 medium (MSWBG11). This medium is prepared in sea water modified for its salinity along with some variations in quantity of inorganic salt content than standard BG11 medium. Salinity of sea water is near to $3.8 \%$ to $4 \%$, this is always adjusted to $3.5 \%$ with addition of little volume of fresh water. Carbonate content is increased by 10 times $\left(\mathrm{Na}_{2} \mathrm{CO}_{3}-0.2 \mathrm{~g} / \mathrm{L}\right)$ than standard $\left(\mathrm{Na}_{2} \mathrm{CO}_{3}-0.02\right.$

\begin{tabular}{|c|c|}
\hline Compound & (g/L) \\
\hline $\mathrm{NaNO}_{3}$ & 1.5 \\
\hline $\mathrm{K}_{2} \mathrm{HPO}_{4} \cdot 3 \mathrm{H}_{2} \mathrm{O}$ & 0.04 \\
\hline $\mathrm{MgSO}_{4} \cdot 7 \mathrm{H}_{2} \mathrm{O}$ & 0.075 \\
\hline $\mathrm{CaCl}_{2} \cdot 2 \mathrm{H}_{2} \mathrm{O}$ & 0.036 \\
\hline $\mathrm{Citric} \mathrm{Acid}$ & 0.006 \\
\hline Ferric Ammonium Citrate & 0.006 \\
\hline $\mathrm{Na}_{2} \mathrm{EDTA}_{2} 2 \mathrm{H}_{2} \mathrm{O}$ & 0.001 \\
\hline $\mathrm{Na}_{2} \mathrm{CO}_{3}$ & 0.2 \\
\hline $\mathrm{H}_{3} \mathrm{BO}_{3}$ & 0.00286 \\
\hline $\mathrm{MnCl}_{2} \cdot 4 \mathrm{H}_{2} \mathrm{O}$ & 0.00181 \\
\hline $\mathrm{ZnSO}_{4} \cdot 7 \mathrm{H}_{2} \mathrm{O}$ & 0.000222 \\
\hline $\mathrm{Na}_{2} \mathrm{MoO}_{4} \cdot 2 \mathrm{H}_{2} \mathrm{O}$ & 0.000390 \\
\hline $\mathrm{CuSO}_{4} \cdot 5 \mathrm{H}_{2} \mathrm{O}$ & 0.000079 \\
\hline $\mathrm{Co}_{2}\left(\mathrm{NO}_{3}\right)_{2} \cdot 6 \mathrm{H}_{2} \mathrm{O}$ & 0.0000494 \\
\hline
\end{tabular}

Table 1: Composition of modified sea water BG11 medium (MSWBG11). $\mathrm{g} / \mathrm{L}$ ). The regular passaging of the culture in total volume of $100 \mathrm{ml}$ liquid medium system was carried out in $250 \mathrm{ml}$ borosilicate Erlenmeyer flask and culture to medium ration maintained at $2: 8 \mathrm{v} / \mathrm{v}$. All the mother stocks in conical flasks were maintained at room temperature on rotary shaker at 100 RPM speed, along with fluorescent light illumination from top. To conduct the various optimization experiments in all the three different PBR systems large volume of the inoculum was required. The culture for inoculum was initially obtained from $1 \mathrm{~L}$ Erlenmeyer flask for $8 \mathrm{~L} \mathrm{PBR}$. Then after optimization of operation of $8 \mathrm{~L} \mathrm{PBR,} \mathrm{culture}$ was always maintained in the same PBR. Then culture for inoculation into the $60 \mathrm{~L}$ PBR system was taken from $8 \mathrm{~L}$ PBR. Same way for 250 L PBR inoculum was obtained from $60 \mathrm{~L}$ PBR which was maintained in it after establishing its working conditions. This way optimization of all the three systems were carried out step by step, as the scaling up was progressed.

\section{Biomass estimation}

Dry weight of biomass (DWB) was estimated by gravimetric analysis. After filtering the water washed algal sample through preweighed Whatman filter paper no. 1 it was allowed to dry overnight at $60^{\circ} \mathrm{C}$ in hot air oven. Overnight dried filter paper along with biomass was weighed and DWB was estimated by subtracting the reading of preweighed Whatman filter paper.

\section{Optimization experiments}

Following experiments were conducted to optimize the operational strategies for each PBR system.

Determining suitable air flow rate for pneumatic agitation: To determine the suitable air flow rate for pneumatic agitation in all the three flat panel PBR systems, different air blowing pumps were employed. Aquarium air pump was utilized for $8 \mathrm{~L}$ and $60 \mathrm{~L}$ PBR. Compressor blower of $1 / 3^{\text {rd }}$ horse power procured from high speed appliances, Mumbai, and this compressor was utilized in $250 \mathrm{~L} \mathrm{PBR}$ as it required heavy air flow rate, which was not achieved with small aquarium pumps. The air flow rate was regulated by acrylic flow meters i.e. rotameters (Napro Scientific, Pune) of 5LPM and 10 LPM capacity. The air flow rates screened were as follows.

\section{8 L - 1 LPM, 2 LPM, 4 LPM}

2. $60 \mathrm{~L}-1$ LPM, 2 LPM, 4 LPM

(Here to achieve 1LPM air flow rate small capacity single aquarium pump was required, to achieve 2 LPM air flow rate single but high capacity aquarium pump was required, whereas for 4 LPM air flow rate 2 high capacity aquarium pumps were employed).

3. $250 \mathrm{~L}-4$ LPM, 6 LPM, 10 LPM (here single compressor motor which blows 12 LPM maximum air was utilized and air flow was adjusted to 4 LPM, 6 LPM and 10 LPM with rotameters)

For this experiment the sparger design selected was random and also the exposure of light intensity kept initially was very less for each system. The inoculums size utilized was $0.16 \mathrm{~g} / \mathrm{L}$ for $8 \mathrm{~L}$ and $60 \mathrm{~L} \mathrm{PBR}$ systems, whereas for $250 \mathrm{~L}$ PBR it was adjusted to $0.25 \mathrm{~g} / \mathrm{L}$. At the suitable air flow rate when biomass found to be uniformly agitating the DWB was determined till 20 days of growth period at every fifth day.

Screening of sparger pore size for optimum algal growth: 'L' shaped sparger with pore sizes of $0.5 \pm 0.1 \mathrm{~mm}, 1 \pm 0.1 \mathrm{~mm}$ and $2 \pm 0.1$ $\mathrm{mm}$ were constructed. These sparges were made from PVC plastic pipe material with $12 \mathrm{~mm}$ ID and $2 \mathrm{~mm}$ thickness. The dimensions such as length and height were decided as per the dimensions of the flat panel $\mathrm{PBR}$, in which it was going to be inserted (Table 2). 


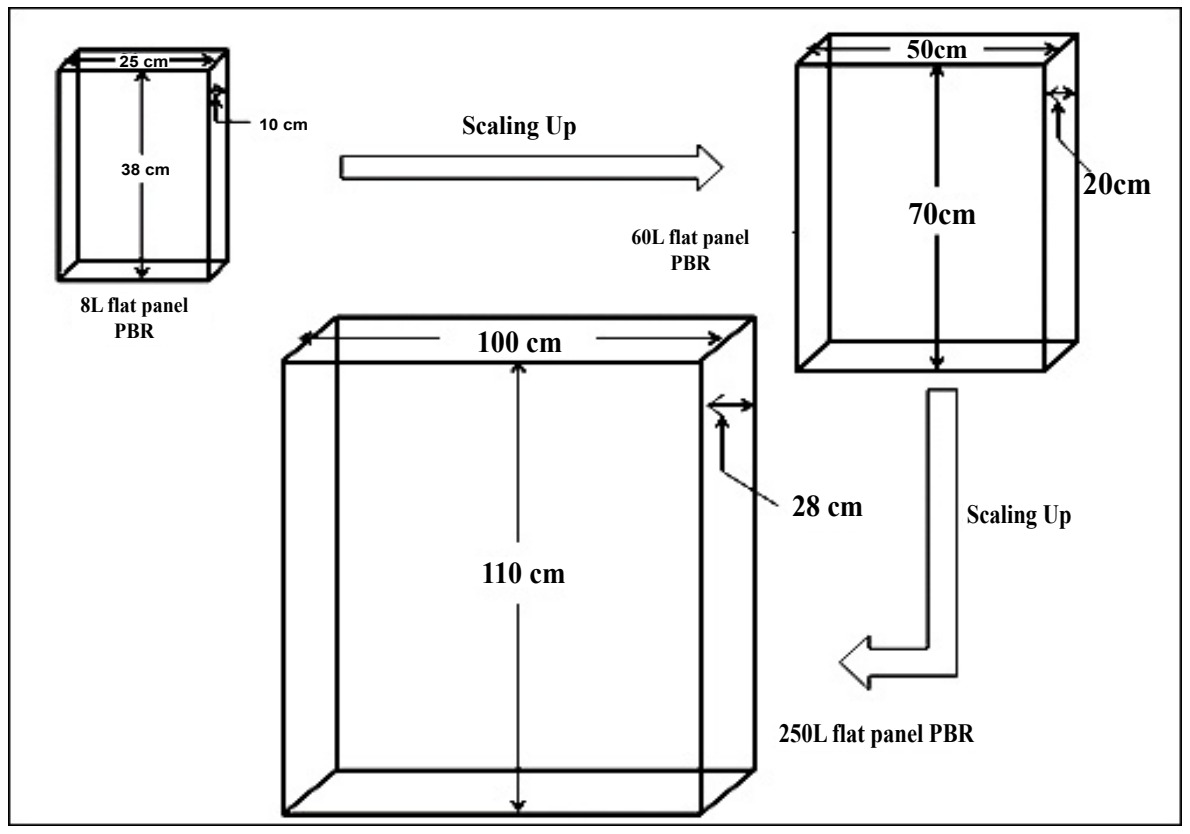

Figure 1: Schematic presentation of 3 flat panel PBRs and their dimensions.

\begin{tabular}{|c|c|c|}
\hline PBR & $\begin{array}{c}\text { Dimension } \\
\text { Length }(\mathrm{cm}) \times \text { Height }(\mathrm{cm})\end{array}$ & $\begin{array}{l}\text { Pore Size or hole diameter } \\
\qquad( \pm 0.1 \mathrm{~mm})\end{array}$ \\
\hline \multirow{3}{*}{$8 \mathrm{~L}$} & \multirow{3}{*}{$20 \times 40$} & 0.5 \\
\hline & & 1.0 \\
\hline & & 2.0 \\
\hline \multirow{3}{*}{$60 \mathrm{~L}$} & \multirow{3}{*}{$45 \times 70$} & 0.5 \\
\hline & & 1.0 \\
\hline & & 2.0 \\
\hline \multirow{3}{*}{$250 \mathrm{~L}$} & \multirow{3}{*}{$90 \times 130$} & 0.5 \\
\hline & & 1.0 \\
\hline & & 2.0 \\
\hline
\end{tabular}

a. Sparger Velocity $(v)=F g /\left(n \times 1 / 4 \pi d i^{2}\right)\left(m s^{-1}\right)$

Where, Fg - Air flow rate in LPM or $\mathrm{m}^{3} \mathrm{~s}^{-1}, \mathrm{n}-$ Number of holes on sparger, di diameter of the sparger hole in $\mathrm{m}$.

b. Reynolds Number $(\mathrm{Re})=4 \rho \mathrm{Fg} / \mathrm{ndin}$

Where, $\rho$ - Liquid density $\left(\mathrm{Kg} \mathrm{m}^{-3}\right), \mathrm{Fg}-$ Gas flow rate in $\mathrm{m}^{3} \mathrm{~s}^{-1}, \mathrm{n}-$ No. of pores,

$\mathrm{di}$ - Pore diameter $(\mathrm{m}), \mathrm{\eta}$ - Liquid dynamic viscosity $\left(\mathrm{Kg} \mathrm{s}^{-1} \mathrm{~m}^{-1}\right)$.

c. Superficial Velocity of gas $(\mathrm{Usg})=\mathrm{VG} / \mathrm{A}\left(\mathrm{m} \mathrm{s}^{-1}\right)$

Where, VG - Volumetric gas flow rate in $\mathrm{m}^{3} \mathrm{~s}^{-1}, A-$ Cross section area of the PBR in $\mathrm{m}^{2}$

d. Gas holdup $(\varepsilon)=(H G-H L) / H G$

Where, HG - Rise in height of liquid level after pneumatic agitation, $\mathrm{HL}$ - Initial height of the liquid without agitation.

Table 2: Details of spargers constructed for each PBR system.

The pair of each type of sparger design was inserted in the respective system and optimized air flow rate was applied for pneumatic agitation through spargers. The light intensity was maintained at low level. Inoculum size was approximately $0.15 \mathrm{~g} / \mathrm{L}$ for $8 \mathrm{~L}$, as well as for $60 \mathrm{~L} \mathrm{PBR}$ and approximately $0.25 \mathrm{~g} / \mathrm{L}$ for $250 \mathrm{~L}$ PBR. The DWB was determined on every five days interval until 20 days growth period and the effect of sparger design on growth of the P. limnetica was observed.

Analysis: Different physico-chemical parameters those changes along with the sparger design and air flow rate employed in flat panel PBR have been studied. To calculate those parameters following formulae were applied and their consequences have been discussed in results and discussion.
Optimization of light intensity: For operation of all PBRs optimization of required light intensity was carried out. For this, vertical white fluorescent tube light panels were constructed. For $8 \mathrm{~L}$ and $60 \mathrm{~L}$ PBRs the light panel containing 6 tube lights, each of 2 feet long was constructed. And for 250 L PBR light panel of 10 tube lights, each of 4 feet long was constructed. The electric switch was given to each tube light present on the assembly, to feasibly operate the panel. The variation in total light intensity was achieved by switching ON or OFF the tube lights. The light intensity was measured with the digital Lux meter device. PBR systems were exposed from 1 feet distance to these panels. For $8 \mathrm{~L}$ we utilized $2000 \pm 500,4000 \pm 500$, and $5000 \pm 500$ Lux light intensities. For $60 \mathrm{~L}$ system $5000 \pm 500,8000 \pm 500$, and 12000 \pm 500 Lux light intensities were screened. For 250 L PBR $12000 \pm 500$, $18000 \pm 500$, and $24000 \pm 500$ Lux light intensities were assessed. The optimized air flow rate and sparger design for respective PBR system was kept constant. The inoculums density was adjusted to equivalent DWB of approximately $0.35 \mathrm{~g} / \mathrm{L}, 0.15 \mathrm{~g} / \mathrm{L}$ and $0.25 \mathrm{~g} / \mathrm{L}$ for $8 \mathrm{~L}, 60 \mathrm{~L}$ and 250 L PBR system respectively. Effect of change in light intensities on the growth of microalgae was elucidated by estimating the DWB of the culture in $\mathrm{g} / \mathrm{L}$ at every 5 days interval until 20 days growth period.

Optimization of inoculum size: After optimization of all the basic physical parameters required for the operation of each above mentioned PBR system, inoculum size for their operation was standardized. By keeping all the optimized parameters constant, different inoculum density equivalent to the DWB of the P. limnetica was utilized. For 8 $\mathrm{L}$ system in laboratory conditions inoculum size corresponding to the DWB of $0.25 \pm 0.05,0.30 \pm 0.05,0.40 \pm 0.05 \mathrm{~g} / \mathrm{L}$ were screened. For $60 \mathrm{~L}$ system, $0.30 \pm 0.05,0.40 \pm 0.05,0.50 \pm 0.05 \mathrm{~g} / \mathrm{L}$ and for $250 \mathrm{~L}$ PBR, 0.40 $\pm 0.05,0.50 \pm 0.05,0.60 \pm 0.05 \mathrm{~g} / \mathrm{L}$ inoculum sizes were experimented. For précised observation DWB of the culture was estimated on every $3^{\text {rd }}$ day instead of 5th day until 18th day of the growth period.

Optimization of inoculum size to operate the PBRs in outdoor conditions: In the extension with previous experiment all the PBRs system were moved to the outside environmental conditions. The 
intensity of the sun light measured was $\sim 65,000-85,000$ Lux and maximum temperature reached in a day period was $\sim 35-38^{\circ} \mathrm{C}$. With optimized operation conditions the effect of inoculum size on growth of algae in outdoor conditions was studied for each PBR system. For this experiment different sets of inoculum range were used. For $8 \mathrm{~L}$ PBR inoculum size corresponding to the DWB of $0.15 \pm 0.05,0.25 \pm 0.05$, $0.35 \pm 0.05 \mathrm{~g} / \mathrm{L}$ were experimented. For $60 \mathrm{~L}$ and $250 \mathrm{~L}$ PBRs $0.25 \pm$ $0.05,0.35 \pm 0.05,0.45 \pm 0.05 \mathrm{~g} / \mathrm{L}$ of inoculum sizes were screened. The observation of DWB of the culture was estimated on every $3^{\text {rd }}$ day until 18th day of the growth period.

\section{Cost estimation for operation of PBRs in laboratory as well as outdoor conditions}

The cost estimation of the operation of each PBR system was carried out per day basis. For indoor conditions the maximum electricity required in kilowatts per day for pneumatic agitation and artificial light exposure was calculated separately. For outdoor operation electricity required only for pneumatic agitation was considered. After determining the electric consumption the electric cost determined as per the basic local electric suppliers charges per unit of electric consumption. Apart from electricity cost, the cost of chemical consumed for preparation of 1 litre medium was also estimated. Total electricity required for one batch of 18 days was calculated along with the total volume of medium utilized and from this final costing was estimated. The quantity of biomass produced at the end of 18 days was used for estimation of maximum cost for production of $1 \mathrm{~kg}$ of dry algal biomass. Attempts were made to discuss the cost effectiveness of the PBR systems when operated in indoor and outdoor environmental conditions.

\section{Results and Discussion}

Photobioreactor is highly attractive approach for mass production of algae due to several advantages such as higher photosynthetic efficiency, higher areal productivity, low contamination, precisely controlled environment and prevention of water loss. Although various types of PBRs have been developed so far, very few microalgal species have been cultured commercially due to poorly developed PBR technology. Intensive efforts that combine theory and practice are still needed to exploit the full potential of PBR's for large scale cultivation. As pointed out by Guo et al. [10], important factors that need to be addressed are light distribution, hydrodynamics, mass transfer and growth kinetics. The present communication deals with the scaling up of the flat panel photobioreactor from $8 \mathrm{~L}$ to $250 \mathrm{~L}$ and optimization of operational strategy for cost effective mass production of halophilic indigenous microalgal strain Pseudanabaena limnetica (Lemm.) Komárek. P. limnetica has been isolated from salt pans of Mumbai suburban region of Maharashtra, India. This strain thrives in alkaline conditions of seawater and has a capacity to sequester anthropogenic $\mathrm{CO}_{2}$. It sustains at high salinity upto $3.5 \%(35,000 \mathrm{ppm})$, temperature of $45^{\circ} \mathrm{C}$ and light exposure of 85,000 Lux of summer season.

Three flat panel PBRs of different volume holding capacities viz. $8 \mathrm{~L}$, $60 \mathrm{~L}$, and $250 \mathrm{~L}$ were constructed from glass material. Their dimensions (length $\times$ height $\times$ breadth) and thickness of the glass material utilized are as follows.

1. $8 \mathrm{~L}$ PBR $-25 \mathrm{~cm} \times 38 \mathrm{~cm} \times 10 \mathrm{~cm}, 4 \mathrm{~mm}$ thick glass.

2. $60 \mathrm{~L}$ PBR $-50 \mathrm{~cm} \times 70 \mathrm{~cm} \times 20 \mathrm{~cm}, 6 \mathrm{~mm}$ thick glass.

3. $250 \mathrm{~L} \mathrm{PBR}-100 \mathrm{~cm} \times 110 \mathrm{~cm} \times 28 \mathrm{~cm}, 12 \mathrm{~mm}$ thick glass.

To operate these PBRs pneumatic agitation was implemented. The pneumatic force was applied through PVC plastic pipe (12 $\mathrm{mm}$ internal diameter, $2 \mathrm{~mm}$ thickness), L shaped spargers. The dimension (length and height) of each sparger was decided from the dimension of the respective PBR in which it would be utilized. Air was passed through a pair of spargers placed on floor of the PBR to achieve agitation.

For the optimization of operational strategies for pneumatically agitated PBR system, air flow rate utilized and sparger pore size are very crucial parameters. Lacking in technical assessment of these two parameters leads to an inadequate or over pneumatic agitation which causes a detrimental effect on growing cyanobacterial species. Therefore, it is essential to optimize them with priority before proceeding to other aspects of mass cultivation in any PBR system.

\section{Optimization of air flow rate}

The growth rate of microalgae increases with increase in aeration rate; as it supports, gas transfer supplies $\mathrm{CO}_{2}$ and creates more frequent access to light. But high flow rate can induce hydrodynamic stress that causes shear damage and adversely affects growth in a bioreactor. In the search of suitable air flow rate for the operation and mass cultivation of P. limnetica in $8 \mathrm{~L}, 60 \mathrm{~L}$ and $250 \mathrm{~L}$ PBR system, different air flow rates have experimented. Effect of different air flow rates was visually observed for the optimum agitation and proper mixing of the culture (Table 3). For $8 \mathrm{~L}$ and $60 \mathrm{~L}$ PBR systems, air flow rate of 1LPM (liter per minute), 2 LPM and 4 LPM were screened. Whereas for $250 \mathrm{~L} \mathrm{PBR}$ systems 4 LPM, 6 LPM, and 10 LPM of air flow rates were evaluated. The parameters other than the air flow rate such as light intensity, inoculum size, growth medium, were kept constant.

For the $8 \mathrm{~L}$ system, when $1 \mathrm{LPM}$ air flow rate was applied for pneumatic agitation, small bubbles were generated from the sparger at a slow flow rate. It was observed that this flow rate was inadequate, which leaded to the stagnation of the whole culture at the bottom of the PBR. When the same experiment was carried out using the air flow rate of $4 \mathrm{LPM}$, at this flow rate, the over agitation of the culture was observed. Unnecessarily high air pressure in sparger leads to uneven air distribution, which generated very large bubbles through few pores situated near the air entrance of the sparger. Due to an inappropriate agitation, some biomass leaded to stagnate at the bottom. At the same time mechanical shear produced by large bubbles lead to the detrimental effect on the algal cells. An adequate agitation was seen when culture was grown with moderate air flow rate of 2 LPM. The system at this flow rate was continuously operated till 20 days. The inoculums size was $0.16 \mathrm{~g} / \mathrm{L}$ of dry weight of the algal biomass (DWB) and the biomass obtained at the end of experiment was $1.32 \mathrm{~g} / \mathrm{L}$.

\begin{tabular}{|c|c|c|c|c|c|c|c|c|c|c|}
\hline $\begin{array}{c}\text { Serial } \\
\text { Number }\end{array}$ & $\begin{array}{l}\text { No. of } \\
\text { Days }\end{array}$ & \multicolumn{9}{|c|}{ Weight of dry Biomass (g/L) } \\
\hline \multicolumn{2}{|c|}{ Photobioreactor } & \multicolumn{3}{|c|}{$8 \mathrm{~L}$} & \multicolumn{3}{|c|}{$60 \mathrm{~L}$} & \multicolumn{3}{|c|}{$250 \mathrm{~L}$} \\
\hline \multicolumn{2}{|c|}{ Air Flow Rate (LPM) } & 1 & 2 & 4 & 1 & 2 & 4 & 4 & 6 & 10 \\
\hline 1. & 0 & \multirow{5}{*}{$\downarrow$} & 0.16 & \multirow{5}{*}{$\uparrow$} & \multirow{5}{*}{$\downarrow$} & \multirow{5}{*}{$\downarrow$} & 0.16 & \multirow{5}{*}{$\downarrow$} & \multirow{5}{*}{$\downarrow$} & 0.25 \\
\hline 2. & 5 & & 0.40 & & & & 0.20 & & & 0.28 \\
\hline 3. & 10 & & 0.56 & & & & 0.35 & & & 0.33 \\
\hline 4. & 15 & & 0.78 & & & & 0.37 & & & 0.39 \\
\hline 5. & 20 & & 1.32 & & & & 0.41 & & & 0.45 \\
\hline
\end{tabular}

Keys:

$\downarrow$ Inadequate Agitation (Very small bubble size, low air pressure inside the sparger, biomass stagnates at the bottom).

$\uparrow$ Over and Inappropriate Agitation (Unnecessarily high air pressure in sparger lead to uneven air distribution. Generate very large bubbles through few pores situated near the air entrance of the sparger. Due to an inappropriate agitation, some biomass found to be stagnated at the bottom. Also, at the same time mechanical shear caused from large bubbles, damaged the cells.)

Table 3: Optimization of air flow rate for $8 \mathrm{~L}, 60 \mathrm{~L}$, and $250 \mathrm{~L}$ capacity flat panel photobioreactors by checking its effect on pneumatic agitation and algal biomass production. 
When the $60 \mathrm{~L}$ PBR system was operated at an air flow rate of 1 and 2 LPM, the efficiency to stir the culture medium was inadequate. Both the air flow rates were found to be inappropriate for the pneumatic agitation as the inoculated culture easily settled at the bottom of the PBR. Whereas at 4 LPM of air flow rate the medium was evenly agitated. The biomass obtained at the end of the $20^{\text {th }}$ day was found to be increased from $0.16 \mathrm{~g} / \mathrm{L}$ to $0.41 \mathrm{~g} / \mathrm{L}$ of DWB. Therefore, 4 LPM air flow rate was shortlisted to pneumatically agitate the algal culture in 60 L PBR system.

For the 250 L PBR system, when 4 LPM of air flow rates was utilized, it was clearly failed to agitate the algal culture. At the flow rate of 6 LPM merely some portion of the culture was found to be agitated and remaining culture was settled at the bottom. Therefore, in the third trial air flow rate was increased to $10 \mathrm{LPM}$. With this flow rate, the inoculated quantity of the culture of $0.25 \mathrm{~g} / \mathrm{L}$ DWB increased to 0.45 $\mathrm{g} / \mathrm{L}$ at the end of 20 days growth period. Hence for the operation of 250 L PBR system appropriate air flow rate for the pneumatic agitation will be 10 LPM.

Other important factors affecting operation of the PBR come into the picture along with the optimization of air flow rate. Those factors are gas holdup $(\varepsilon)$ and superficial velocity of the gas (Usg). Gas holdup and superficial velocity both were found to be increasing with increasing air flow rate in an individual PBR system. Maximum gas holdup and superficial velocity are always essential for the volumetric mass transfer (KLa) of the gases such as $\mathrm{CO}_{2}, \mathrm{O}_{2}$ into the liquid [11]. But the continuous increase in Usg could be a cell growth limiting factor after a certain point. Table 4 gives the various flow rates used for pneumatic agitation in different flat panel PBRs and the corresponding gas hold-up and superficial velocities were determined for the different air flow rates. The effect of increasing Usg on the growth of $P$. limnetica was observed and it was explained earlier that for $8 \mathrm{~L} \mathrm{PBR} \mathrm{system}$ moderate air flow rate (i.e., 2 LPM) was optimum along with its corresponding Usg value. Whereas the higher air flow rate of 4 LPM with increased Usg value was not suitable for algae cultivation in $8 \mathrm{~L}$ PBR. The filaments of P. limnetica came in contact with the large air bubble produced at this Usg was broken into the fine fragments, and caused cell damage. In other two PBR models, as explained earlier, the maximum airflow rate employed was found to be ideal along with its corresponding Usg and gas hold-up values. Many authors have reported that increasing Usg beyond certain $\mathrm{mm} / \mathrm{s}$ shows the negative effect on cell growth. Vega-Estrada et al. [12], used a split-cylinder airlift PBR of $2 \mathrm{~L}$ capacity and found that Haematococcus pluvialis cells were sensitive for gas velocities greater than $12 \mathrm{~mm} / \mathrm{s}$. Miron et al. [13] found that Phaeodactylum tricornutum cells became susceptible when velocity exceeded $10 \mathrm{~mm} / \mathrm{s}$. Our data shows that $P$. limnetica is very much susceptible to the hydrodynamic stress caused due to the superficial velocity of $2.66 \mathrm{~mm} / \mathrm{s}$ and beyond, as other noted algal species. Merchuk [14] found Usg values between $0.54 \mathrm{~mm} / \mathrm{s}$ and 8.2 $\mathrm{mm} / \mathrm{s}$ have the negative effect on the growth of Porphyridium sp. On the other hand Barbosa et al. [15], Used higher velocity values for $D$. tertiolecta $(76 \mathrm{~mm} / \mathrm{s})$ and Chlamydomonas reinhardtii $(85 \mathrm{~mm} / \mathrm{s})$ and did not see negative effect on growth. Similarly Falinski et al. [16], used $600 \mathrm{ml}$ airlift PBR for the cultivation of marine microalga Tisochrysis lutea and found that superficial gas velocity more than $93 \mathrm{~mm} / \mathrm{s}$ was not harmful but advantageous. Therefore, here it was concluded that for different species of microalgae there is a different threshold for tolerance of hydrodynamic stress and corresponding critical Usg value also differs.

The effect of aeration rate on superficial gas velocity Usg, mass transfer coefficient KLa and growth rate have been studied by many researchers [12,15]. However, the design aspects of sparger remain ignored [17]. The sparger design plays a decisive role because bubble distribution mainly governs the mass transfer and gas holdup through an interfacial area of the photobioreactor. As observed by many authors the cell density increases linearly with an increase in flow rate. As the superficial velocity of the gas increases the cell density increases. Also, there is a linear correlation between superficial gas velocity and mass transfer coefficient KLa [16]. To test the effects of bubble size through varying pore sizes of different sparger designs on growth rate of Isochrysis galbana (T-ISO) CCMP 1324, Falinski [18] used (1) a fine pore diffuser with smaller diameter pores, bubble size $0.5 \mathrm{~mm}$ to $2 \mathrm{~mm}$, (2) a medium pore diffuser, bubble size $1 \mathrm{~mm}$ to $3 \mathrm{~mm}$, and (3) 3.2 $\mathrm{mm}$ diameter open glass pipet, which produced bubble size of much greater than the bubble size of the other 2 spargers. The air flow rate was maintained constant at $2 \mathrm{vvm}$. She observed when the same flow rate was introduced through different sparger bearing different pore sizes, the growth rate varied. The smallest pore size sparger was responsible for lowest cell growth. The higher cell growth was observed in with the medium pore size air diffuser. These findings indicate that efforts should focus on reducing sparger velocity and optimal bubble size that will enhance the growth. Therefore our further study was in context to pore size of the sparger.

\section{Effect of sparger pore size}

The pore size of the sparger plays important role in directing the performance of the sparger. Inappropriate design leads to the inefficient working of the photobioreactor system.

For the experiments conducted to find out the suitable sparger pore size for $8 \mathrm{~L}, 60 \mathrm{~L}$, and $250 \mathrm{~L}$ system, the air flow rate optimized for each system from the previous experiment (Table 3 ) were kept constant. The standard inoculums size of $0.15 \mathrm{~g} / \mathrm{L}$ for $8 \mathrm{~L}$ and $60 \mathrm{~L}$, and $0.25 \mathrm{~g} / \mathrm{L}$ for 250 $\mathrm{L}$ capacity photobioreactor was used. 'L'shaped sparger with pore sizes of $0.5 \pm 0.1 \mathrm{~mm}, 1 \pm 0.1 \mathrm{~mm}$ and $2 \pm 0.1 \mathrm{~mm}$ were screened for different PBRs. The effect of sparger pore size on the growth of $P$. limnetica was obtained at every 5 days interval till 20 days (Table 5).Effect of pore size on sparger velocity $(v)$ and Reynolds number $(\mathrm{Re})$ at orifice was calculated and tabulated in Table 6.

The DWB for $8 \mathrm{~L}$ at $0.5 \pm 0.1 \mathrm{~mm}$ and $2 \pm 0.1 \mathrm{~mm}$ sparger pore size was found to be $0.30 \mathrm{~g} / \mathrm{L}$ and $0.88 \mathrm{~g} / \mathrm{L}$ respectively which were very less

\begin{tabular}{|c|c|c|c|c|c|c|c|c|c|c|}
\hline \multirow{3}{*}{ Sr. No } & \multirow{3}{*}{$\begin{array}{c}\text { No. of Days } \\
\text { PBR } \\
\text { Pore Size }(\mathrm{mm})\end{array}$} & \multicolumn{9}{|c|}{ Weight of dry Biomass (g/L) } \\
\hline & & \multicolumn{3}{|c|}{$8 \mathrm{~L}$} & \multicolumn{3}{|c|}{$60 \mathrm{~L}$} & \multicolumn{3}{|c|}{$250 \mathrm{~L}$} \\
\hline & & $0.5 \pm 0.1$ & $1 \pm 0.1$ & $2 \pm 0.1$ & $0.5 \pm 0.1$ & $1 \pm 0.1$ & $2 \pm 0.1$ & $0.5 \pm 0.1$ & $1 \pm 0.1$ & $2 \pm 0.1$ \\
\hline 1 & 0 & 0.15 & 0.16 & 0.15 & 0.14 & 0.15 & 0.16 & 0.27 & 0.24 & 0.25 \\
\hline 2 & 5 & 0.09 & 0.4 & 0.48 & 0.1 & 0.15 & 0.2 & 0.25 & 0.25 & 0.28 \\
\hline 3 & 10 & 0.2 & 0.56 & 0.55 & 0.15 & 0.17 & 0.35 & 0.27 & 0.3 & 0.33 \\
\hline 4 & 15 & 0.26 & 0.78 & 0.72 & 0.19 & 0.25 & 0.37 & 0.3 & 0.34 & 0.39 \\
\hline 5 & 20 & 0.3 & 1.32 & 0.88 & 0.24 & 0.28 & 0.41 & 0.34 & 0.39 & 0.45 \\
\hline
\end{tabular}

Table 4: Screening of spargers with different pore sizes (viz. $0.5 \pm 0.1 \mathrm{~mm}, 1 \pm 0.1 \mathrm{~mm}, 2 \pm 0.1 \mathrm{~mm}$ ) for $8 \mathrm{~L}, 60 \mathrm{~L}$, and $250 \mathrm{~L}$ capacity flat panel PBRs. 


\begin{tabular}{|c|c|c|c|c|c|}
\hline PBR & $\begin{array}{l}\text { Air Flow Rate } \\
\left(\mathrm{m}^{3} / \mathrm{s}\right)\end{array}$ & $\begin{array}{l}\text { Pore Size or hole diameter }( \pm \\
0.1 \mathrm{~mm})\end{array}$ & $\begin{array}{l}\text { Sparger velocity } \\
\text { (v) }(\mathrm{m} / \mathrm{s})\end{array}$ & $\begin{array}{l}\text { Reynolds number } \\
\text { (Re) }\end{array}$ & $\begin{array}{l}\text { DWB } \\
\text { (g/L) }\end{array}$ \\
\hline \multirow{3}{*}{$8 \mathrm{~L}$} & \multirow{3}{*}{$2 \mathrm{~L}\left(3.33 \times 10^{-5}\right)$} & 0.5 & 1.091 & 7,023 & 0.30 \\
\hline & & 1.0 & 0.273 & 3,512 & 1.32 \\
\hline & & 2.0 & 0.123 & 3,160 & 0.88 \\
\hline \multirow{3}{*}{$60 \mathrm{~L}$} & \multirow{3}{*}{$4 \mathrm{~L}\left(6.66 \times 10^{-5}\right)$} & 0.5 & 0.982 & 6,321 & 0.24 \\
\hline & & 1.0 & 0.327 & 4,214 & 0.28 \\
\hline & & 2.0 & 0.123 & 3,160 & 0.41 \\
\hline \multirow{3}{*}{$250 \mathrm{~L}$} & \multirow{3}{*}{$10 \mathrm{~L}\left(1.66 \times 10^{-4}\right)$} & 0.5 & 1.780 & 11,458 & 0.34 \\
\hline & & 1.0 & 0.544 & 7,002 & 0.39 \\
\hline & & 2.0 & 0.136 & 3,501 & 0.45 \\
\hline
\end{tabular}

Table 5: Estimation of sparger velocity (v), Reynolds number for different spargers at optimized air flow rate, and checking their effect on growth of $P$. limnetica in three different flat panel PBR systems.

\begin{tabular}{|c|c|c|c|c|c|c|c|c|c|}
\hline \multirow{2}{*}{$\begin{array}{l}\text { Air flow rate } \\
\text { per Minute } \\
\text { (LPM) }\end{array}$} & \multicolumn{3}{|c|}{ Gas holdup $(\varepsilon)$} & \multicolumn{3}{|c|}{ Superficial Velocity of gas (Usg) (m/s) } & \multicolumn{3}{|c|}{ DWB (g/L) } \\
\hline & $8 \mathrm{~L}$ & $60 \mathrm{~L}$ & $250 \mathrm{~L}$ & $8 \mathrm{~L}$ & $60 \mathrm{~L}$ & $250 \mathrm{~L}$ & $8 \mathrm{~L}$ & $60 \mathrm{~L}$ & $250 \mathrm{~L}$ \\
\hline $1-2$ & $1.69 \times 10^{-2}$ & $3.98 \times 10^{-3}$ & - & $6.64 \times 10^{-4}$ & $1.66 \times 10^{-6}$ & - & - & - & - \\
\hline $2-3$ & $1.96 \times 10^{-2}$ & $9.90 \times 10^{-3}$ & - & $1.33 \times 10^{-3}$ & $3.33 \times 10^{-4}$ & - & 1.32 & - & - \\
\hline $3-4$ & $2.6 \times 10^{-2}$ & $1.18 \times 10^{-2}$ & $2.49 \times 10^{-3}$ & $2.66 \times 10^{-3}$ & $6.66 \times 10^{-4}$ & $2.37 \times 10^{-4}$ & - & 0.41 & - \\
\hline $5-7$ & - & - & $3.73 \times 10^{-3}$ & - & - & $3.57 \times 10^{-4}$ & - & - & - \\
\hline $9-11$ & - & - & $6.21 \times 10^{-3}$ & - & - & $5.95 \times 10^{-4}$ & - & - & 0.45 \\
\hline
\end{tabular}

Table 6: The data of gas holdup and superficial gas velocity $(\mathrm{m} / \mathrm{s})$ in pneumatically agitated $8 \mathrm{~L}, 60 \mathrm{~L}$ and $250 \mathrm{~L}$ Flat panel photobioreactor, along with DWB (g/L) obtained after optimization of necessary light intensity (indoor operational strategies in Table 7).

than the DWB obtained with $1 \pm 0.1 \mathrm{~mm}$ of pore size i.e. $1.32 \mathrm{~g} / \mathrm{L}$. From the Results obtained it was seen that the sparger system with medium pore size $(1 \pm 0.1 \mathrm{~mm})$ suits well (Figure 2$)$. Sparger with pore size of 0.5 $\pm 0.1 \mathrm{~mm}$ gave very fine bubbles, which were inefficient in pneumatic agitation and another sparger with pore size of $2 \pm 0.1 \mathrm{~mm}$ was giving a larger bubble which was creating a sheer effect when each bubble bust.

For 60 L PBR system, results obtained showed that neither $0.5 \pm 0.1$ $\mathrm{mm}$, nor $1 \pm 0.1 \mathrm{~mm}$ pore size spargers are suitable for the growth of algae as maximum DWB achieved with these pore sizes were only 0.24 $\mathrm{g} / \mathrm{L}$ and $0.28 \mathrm{~g} / \mathrm{L}$ respectively. Biomass obtained with $2 \pm 0.1 \mathrm{~mm}$ pore sized sparger is $0.41 \mathrm{~g} / \mathrm{L}$ which was higher than that of $0.5 \pm 0.1 \mathrm{~mm}$ and $1 \pm 0.1 \mathrm{~mm}$ pore size spargers. Therefore sparger with pore size of $2 \pm$ $0.1 \mathrm{~mm}$ was found to be suitable (Figure 3 ) hence; this sparger design was shortlisted for the operation of $60 \mathrm{~L}$ PBR.

For the $250 \mathrm{~L}$ capacity PBR system, the DWB obtained after 20 days with a sparger pore size of $0.5 \pm 0.1 \mathrm{~mm}$ and $1 \pm 0.1 \mathrm{~mm}$ was only 0.34 $\mathrm{g} / \mathrm{L}$ and $0.39 \mathrm{~g} / \mathrm{L}$ respectively. Whereas the DWB obtained with sparger pore size of $2 \pm 0.1 \mathrm{~mm}$ was $0.45 \mathrm{~g} / \mathrm{L}$ which was little higher and better than the biomass obtained with the other two spargers. Therefore for the operation of $250 \mathrm{~L}$ system sparger with the pore size of $2 \pm 0.1 \mathrm{~mm}$ was shortlisted (Figure 4). But in this design, due to the large length of the sparger percentage extent of non-uniformity (ENU) was observed. Kulkarni et al. [17] have explained that in straight pipe sparger extent of non-uniformity always increases with an increase in sparger pore or hole diameter and length of pipe. This extent of non-uniformity didn't harm the growing culture, and considerable agitation was achieved, but clogging of the sparger was very common at the end of every batch, as biomass enters into the sparger, it blocks the airway. This increases the laborious work of cleaning and maintenance of the sparger system.

At optimized air flow rate for each PBR, the effect of varying pore size on sparger velocity $(v)$ in $\mathrm{m} / \mathrm{s}$ and Reynolds number $\left(\mathrm{R}_{\mathrm{e}}\right)$ was determined (Table 6). Sparger velocity is the maximum velocity at which bubbles penetrate into the liquid. Sparger velocity varies with the liquid density, viscosity, air flow rate, pore size and number of pores on individual sparger design [15]. While short listing sparger design, the sparger velocity along with Reynolds number $\left(\mathrm{R}_{\mathrm{e}}\right)$ is calculated for different spargers. As seen in Table 6, as diameter of the pore increases the sparger velocity $(v)(\mathrm{m} / \mathrm{s})$ and Reynolds number $\left(R_{e}\right)$ decreases. A decrease in sparger velocity supports cell growth. This is also depicted in Figures 5, 6 and 7 for $8 \mathrm{~L}, 60 \mathrm{~L}$, and $250 \mathrm{~L}$ photobioreactors, as sparger pore size increases there is a decrease in sparger velocity and as sparger velocity decreases the biomass increases. Literature also supports, increase in sparger velocity have the negative effect on cell growth [18]. Falinski [18] has studied the effect of different aeration conditions on Isochrysis galbana (T-ISO) CCMP 1324 in a bench-scale photobioreactor. She used sparger with orifice diameter $3.2 \mathrm{~mm}, 1.6 \mathrm{~mm}$, $0.84 \mathrm{~mm}$, and $0.59 \mathrm{~mm}$ for $0.6 \mathrm{~L}$ internal loop airlift photobioreactor. As sparger diameter increased, there was a drastic reduction in both sparger velocity and Reynolds number was observed. High sparger velocity leads to the generation of shear stress which negatively affects the cell growth. Silva et al. [19] firstly stated that shear stress exerted by breaking bubbles at sparger site could be a possible cause of cell damage in Dunaliella sps. Modified orifice Reynolds number calculated by them under their experimental conditions was increased from 99,000 to 188,000 , as specific gas flow rate was increased. Progression in the modified orifice Reynolds number leads to the corresponding decrease in the cells productivity $3 \mathrm{~cm} 1 \mathrm{~h}$, which was the consequence of hydrodynamic stress exerted by gas bubbling. Later, Suzuki et al. [20] found that the death rate of $D$. tertiolecta increased with an increased sparger velocity between $13 \mathrm{~m} / \mathrm{s}$ and $125 \mathrm{~m} / \mathrm{s}$. Barbosa et al. [15] investigated and found that sparger velocities of $66.3 \mathrm{~m} / \mathrm{s}$ and $\mathrm{R}$ approximately 35,300 contributed to the death of $H$. pluvialis cultures. While sparger velocity $7.4 \mathrm{~m} / \mathrm{s}$ along with $\mathrm{R}_{\mathrm{e}}$ approximately 3900 , did not have the detrimental effect and concluded that there was likely a critical sparger velocity for each species. Thus, for each algal species it is essential to optimize air flow rate and sparger pore size to achieve optimal growth. Agitated 8 L, $60 \mathrm{~L}$ and $250 \mathrm{~L}$ flat panel photobioreactor, along with DWB (g/L) obtained after optimization of necessary light intensity (indoor operational strategies in Table 7). 


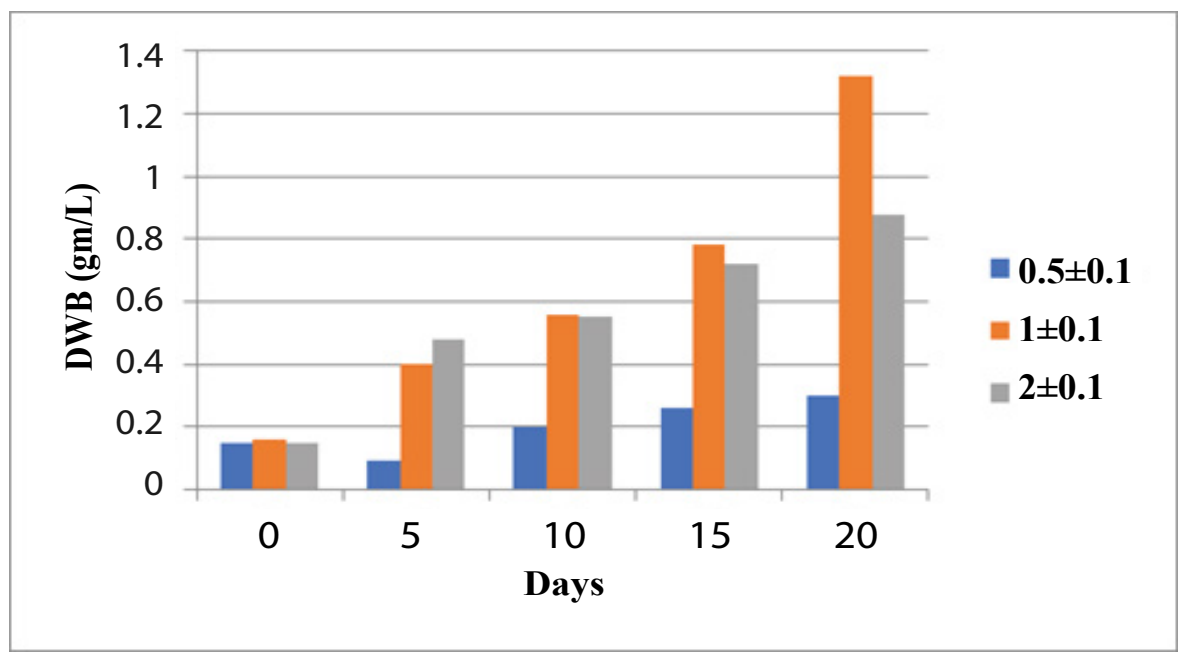

Figure 2: Effect of sparger pore size (8 L flat plate PBR).

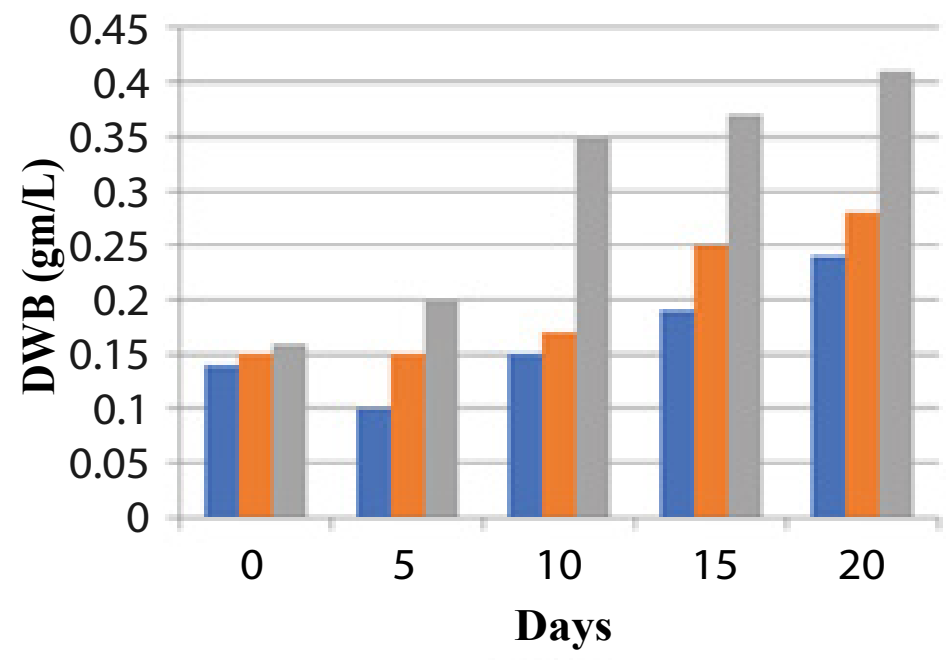

$0.5 \pm 0.1$

$1 \pm 0.1$

$2 \pm 0.1$

Figure 3: Effect of sparger pore size (60 L flat plate PBR)

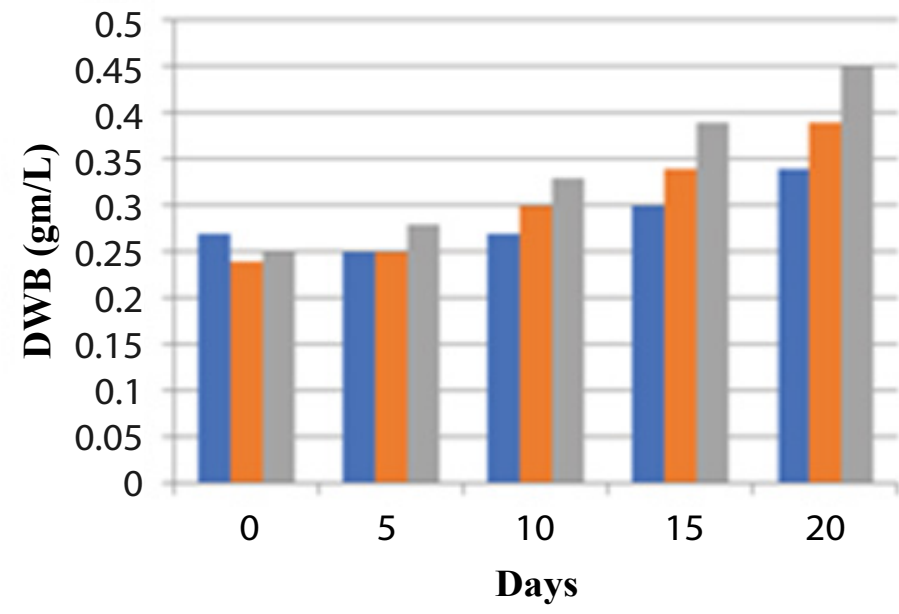

$=0.5 \pm 0.1$

$=1 \pm 0.1$

$=2 \pm 0.1$

Figure 4: Effect of sparger pore size (250 L flat plate PBR). 
Citation: Magar CS, Deodhar MA (2018) Operational Strategies for Cost Effective Mass Cultivation of Halophilic Microalgal Strain Pseudanabaena limnetica in 1000 L Flat Panel Photobioreactor. J Pet Environ Biotechnol 9: 380. doi: 10.4172/2157-7463.1000380

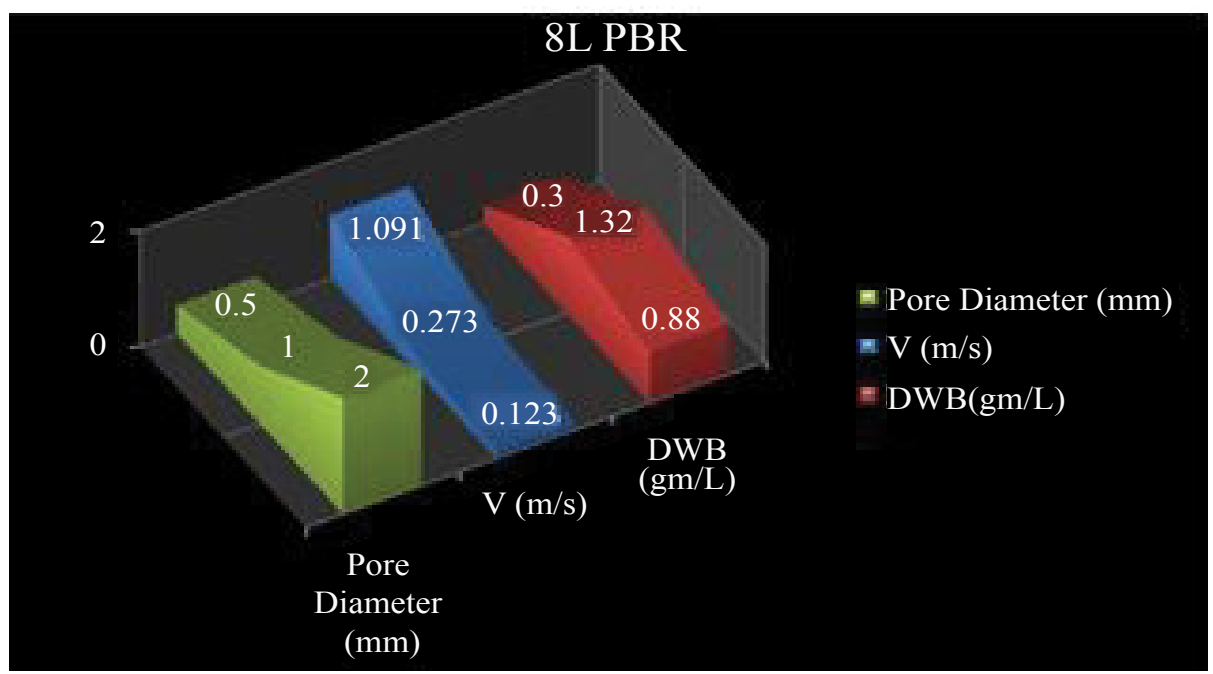

Figure 5: Effect of sparger pore size $(\mathrm{mm})$ on sparger velocity $v(\mathrm{~m} / \mathrm{s})$ and DWB $(\mathrm{gm} / \mathrm{L})$ in $8 \mathrm{~L}$ flat plate PBR.

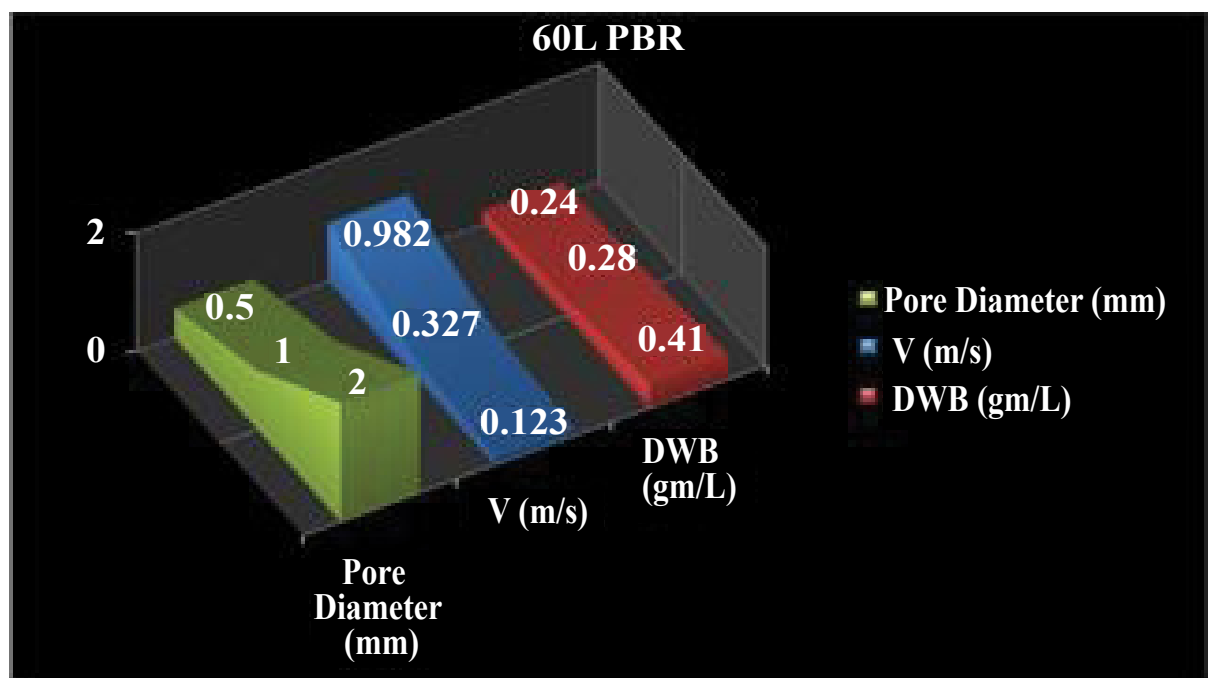

Figure 6: Effect of sparger pore size $(\mathrm{mm})$ on sparger velocity $v(\mathrm{~m} / \mathrm{s})$ and DWB $(\mathrm{gm} / \mathrm{L})$ in $60 \mathrm{~L}$ flat plate PBR.

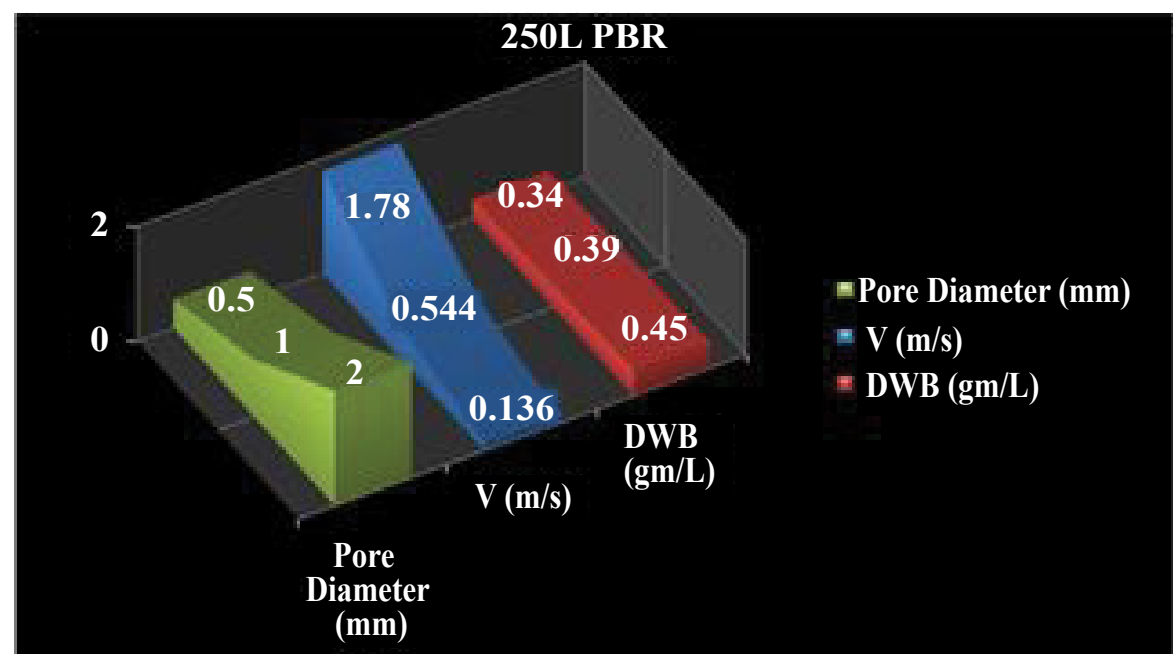

Figure 7: Effect of sparger pore size $(\mathrm{mm})$ on sparger velocity $\vee(\mathrm{m} / \mathrm{s})$ and DWB $(\mathrm{gm} / \mathrm{L})$ in $250 \mathrm{~L}$ flat plate PBR 
Being a photosynthetic organism, cyanophytes need sufficient amount of light exposure to receive photons for biochemical conversion of $\mathrm{CO}_{2}$ into sugar molecules. Therefore, after optimization of air flow rate and sparger design for operation of each PBR system, determination of most favorable light exposure is the necessity.

\section{Optimization of light intensity}

Coutteau [7] stated that light intensity plays an important role, but the requirements vary greatly with the depth and the density of the algal culture: at higher depths and cell concentrations the light intensity must be increased to penetrate through the culture (e.g. 1,000 Lux is suitable for Erlenmeyer flasks, 5,000-10,000 is required for larger volumes). Accordingly to operate our three flat panel PBR systems viz. $8 \mathrm{~L}, 60$ $\mathrm{L}$, and $250 \mathrm{~L}$ in laboratory conditions, we have carried out screening experiments for different light intensities. For this, white fluorescent tube light vertical panels were used. These panels were placed at about 1 foot distance from flat surface of the PBRs. For $8 \mathrm{~L}$ we utilized $2000 \pm$ $500,4000 \pm 500$, and $5000 \pm 500$ Lux light intensities. For $60 \mathrm{~L}$ system $5000 \pm 500,8000 \pm 500$, and $12000 \pm 500$ Lux light intensities were screened. For 250 L PBR $12000 \pm 500,18000 \pm 500$, and $24000 \pm 500$ Lux light intensities were assessed. Effect of these light intensities on the growth of microalgae was elucidated by estimating the DWB of the culture in $\mathrm{g} / \mathrm{L}$ at every 5 days interval till the end of 20 days growth period (Table 7).

For $8 \mathrm{~L}$ PBR inoculums size used was $0.35 \pm 0.05 \mathrm{~g} / \mathrm{L}$ for all the three sets of light intensities. When culture was exposed to $2000 \pm 500$ Lux of light intensity the DWB obtained at the end of the $20^{\text {th }}$ day was $1.17 \mathrm{~g} / \mathrm{L}$. The effect of $4000 \pm 500$ Lux light intensity was found to be more appealing as DWB on 15th day itself was $1.20 \mathrm{~g} / \mathrm{L}$, which was higher than the DWB obtained with $2000 \pm 500$ Lux of light intensity. Further exposure with the same intensity of light improved the biomass to $1.28 \mathrm{~g} / \mathrm{L}$ on the $20^{\text {th }}$ day. The higher light intensity was found to be inhibitory. At $5000 \pm 500$ Lux light intensity, DWB obtained till the $20^{\text {th }}$ day was only $0.80 \mathrm{~g} / \mathrm{L}$ (Table 7 and Figure 8 ). The explanation for these results could be obtained by Coutteau [7], that too high light intensity (e.g. direct sunlight, small container close to artificial light) may result in photo-inhibition. This may cause overheating due to both natural and artificial illumination. $8 \mathrm{~L}$ PBR system has only $10 \mathrm{~cm}$ of breadth (distance between two light exposed flat surfaces) to which $5000 \pm$ 500 Lux light intensity would have been too high which ultimately suppressed the growth of the organism by photoinhibition. This also can be in a reciprocal with the observations made by Pal et al. [21] who states that the higher the lux the slower the growth rate. In the growth phase of Chaetoceros muelleri when cultured in $250 \mathrm{ml}$ conical flasks and exposed to around 2000 Lux and 2500 Lux light intensity the initial fast growth slows down. There might be few factors affecting this, and one could be the light intensity too high for the cells to tolerate. Hence this indicates that too much light is not suitable for the growth of $C$. muelleri.

In case of $60 \mathrm{~L}$ PBR system, inoculum size was maintained constant at $0.30 \pm 0.05 \mathrm{~g} / \mathrm{L}$ for all the three sets of light intensities as mentioned earlier. The DWB noted at the end of the $20^{\text {th }}$ day for $5000 \pm 500,8000$ \pm 500 , and $12000 \pm 500$ Lux light intensities were $0.64 \mathrm{~g} / \mathrm{L}, 1.00 \mathrm{~g} / \mathrm{L}$, and $1.54 \mathrm{~g} / \mathrm{L}$ respectively (Table 7 and Figure 9 ). Similar results were obtained for $250 \mathrm{~L}$ PBR system, which was operated at the inoculum size of 0.25 $\pm 0.05 \mathrm{~g} / \mathrm{L}$ for all the three sets of light intensities. The DWB noted for $12000 \pm 500,18000 \pm 500$, and $24000 \pm 500$ Lux light intensities were $0.40 \mathrm{~g} / \mathrm{L}, 0.73 \mathrm{~g} / \mathrm{L}$, and $0.80 \mathrm{~g} / \mathrm{L}$ respectively by the end of the $20^{\text {th }}$ day (Table 7) (Figure 10). Thus in $250 \mathrm{~L}$ PBR in all the light intensities the biomass produced was lesser than that of $60 \mathrm{~L} \mathrm{PBR}$. The reason for this observation could be increasing breadth of the PBR system. $60 \mathrm{~L}$ system possess $20 \mathrm{~cm}$ of breadth whereas $250 \mathrm{~L}$ system has $28 \mathrm{~cm}$. Due to increasing breadth the light penetration into the PBR systems becomes limited, which necessitates the increase in light exposure to fulfil the light requirement of growing cyanobacterial culture. Therefore, it can be concluded that $250 \mathrm{~L}$ flat panel PBR require a very high amount of light irradiation to operate these systems in laboratory conditions. This would increase the electricity consumption and corresponding electric cost in their operation, which has discussed later in this paper. It is also apparent from the observations that increasing breadth beyond $20 \mathrm{~cm}$ increases the light path length into the PBR system. Hence, breadth of the PBR should not exceed $20 \mathrm{~cm}$. This limits the growth of culture in PBR. For cost effectiveness the PBR could be operated in outdoor natural light conditions.

Distribution of light intensity is not uniform in the PBR. Light intensity decreases exponentially with distance away from irradiated side. Light can penetrate few millimeters when the cell density becomes high. Hence, the microalgal growth rate significantly decreases as PBR breadth increases. PBR can be divided into three distinct zones. First is a strong illumination zone which has inhibitory effect on cell growth. Then comes weak illumination zone where light is just enough for maintenance of cells, and finally comes the dark zone. Pneumatic agitation brings about shuttling of the microalgal cells from photic zone to dark zone, which brings about flashing light effect or favorable periodic light and dark cycles which enhances the photosynthesis and growth [22]. The large optical path around $0.2 \mathrm{~m}$ and poor mixing of culture results in long light and dark cycles in the system which contributes to lower areal productivity. Flat panel PBR with shorter optical path minimizes the dark zone in the culture [23].

Qiang et al. [24] elaborated on combined effect of light intensity, light path and culture density on output of Spirulina platensis. They claimed that for effective use of high energy irradiance e.g. outdoor cultivation during summer days, the essential things are short light path, ultra high cell densities and highly turbulent air flow. For each irradiance (photon flux density), there was optimal culture density (OCD) that is the algal concentration that yielded highest algal cell biomass. The requirement of OCD rose with increasing flux density. At highest irradiance (8000 $\mu \mathrm{mol} \mathrm{m}{ }^{-2} \mathrm{~s}^{-1}$ ), which is 3-4 times higher irradiation at mid-day summer the algae produced biomass of $16.8 \mathrm{~g}$ of dry weight $\mathrm{m}^{-2} \mathrm{~h}^{-1}$. This means that as irradiance increases the inoculum size has to be increased. To study the effect of light path the reactors employed consist of the width ranging from $7.5 \mathrm{~mm}$ to $200 \mathrm{~mm}$. They observed that output rate drastically increases when the width decreases beyond $50 \mathrm{~mm}$. The output rate increased by 50 fold when light path was reduced from 200 $\mathrm{mm}-7.5 \mathrm{~mm}$. But the experiment was carried out at light intensity of $900 \mu \mathrm{mol} \mathrm{m} \mathrm{m}^{-2} \mathrm{~s}^{-1}$.

Contrary to this Zou and Richmond [25], studied the effect of light path length on cell mass and production of eco-sapentaenoic acid (EPA) in flat panel PBR operated in outdoor conditions where, optimum light intensity was found to be ranging between 1800 to 2100 $\mu \mathrm{mol} \mathrm{m} \mathrm{m}^{-2} \mathrm{~s}^{-1}$. The light path was increased from $1.3 \mathrm{~cm}$ to $17.00 \mathrm{~cm}$. In summer biomass productivity was $22.4 \mathrm{~g}$ dry weight per day $\mathrm{m}^{-2}$ and EPA productivity was $515.7 \mathrm{mg} \mathrm{m}^{-2}$. They concluded that the optimum light path must be defined with each algal species.

\section{Optimization of culture inoculum size}

Low yield have been one of the major limiting factor in mass production of algae. Attainment of maximal productivity and its 


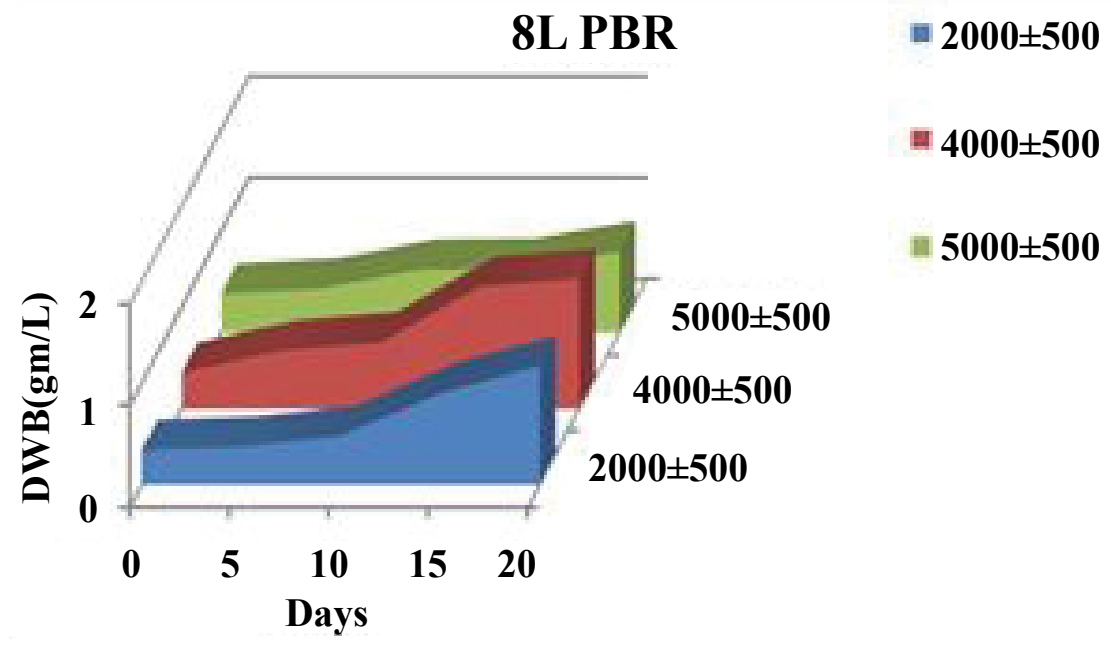

Figure 8: Effect of light intensity on DWB in $8 \mathrm{~L}$ flat plate PBR.
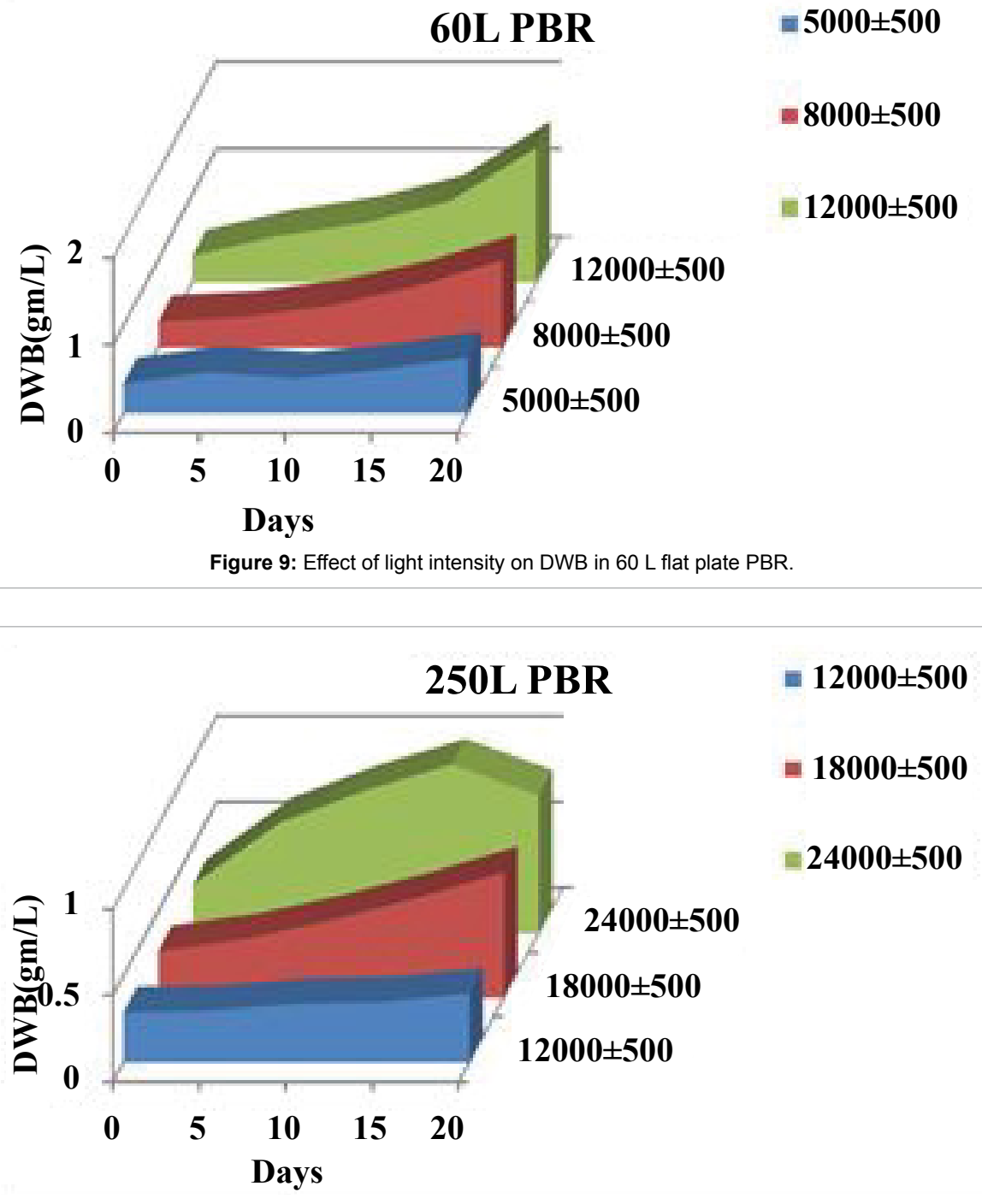

Figure 10: Effect of light intensity on DWB in $250 \mathrm{~L}$ flat plate PBR. 
Citation: Magar CS, Deodhar MA (2018) Operational Strategies for Cost Effective Mass Cultivation of Halophilic Microalgal Strain Pseudanabaena limnetica in 1000 L Flat Panel Photobioreactor. J Pet Environ Biotechnol 9: 380. doi: 10.4172/2157-7463.1000380

Page 11 of 16

maintenance should be one of the most important operational objectives [26]. Hu et al. [27] studied the growth of Spirulina platensis using a flat plate photo-bioreactor. The results revealed the important rule for cultivation of microalgae, which is when the cell density is in the optimal range, can highest productivity be achieved. After optimization of physical parameters, like Air flow rate, Sparger pore size, the Light intensity for each flat panel PBR, optimum inoculum size required for their operation was estimated.

For $8 \mathrm{~L}$ system, inoculum size corresponding to the DWB of $0.25 \pm$ $0.05,0.30 \pm 0.05,0.40 \pm 0.05 \mathrm{~g} / \mathrm{L}$ were screened. For $60 \mathrm{~L}$ system, $0.30 \pm$ $0.05,0.40 \pm 0.05,0.50 \pm 0.05 \mathrm{~g} / \mathrm{L}$ and for $250 \mathrm{~L} \mathrm{PBR}, 0.40 \pm 0.05,0.50 \pm$ $0.05,0.60 \pm 0.05 \mathrm{~g} / \mathrm{L}$ inoculum quantities were experimented (Table 8).

As seen in Figure 11, in laboratory condition for $8 \mathrm{~L}$ PBR in inoculum size $0.25 \pm 0.05 \mathrm{~g} / \mathrm{L}$, the lag phase was persistent until almost 15 days of the growth period. The biomass produced on the $15^{\text {th }}$ day was $0.38 \mathrm{~g} / \mathrm{L}$ which was increased to only $0.57 \mathrm{~g} / \mathrm{L}$ till the $18^{\text {th }}$ day. When the inoculum size was $0.30 \pm 0.05 \mathrm{~g} / \mathrm{L}$ the culture was found to be in the lag phase of growth till 6th day and the biomass obtained was 0.47 $\mathrm{g} / \mathrm{L}$. On the $9^{\text {th }}$ day, it reached to $0.64 \mathrm{~g} / \mathrm{L}$. suddenly on the $12^{\text {th }}$ day, the biomass production increased prominently to $0.90 \mathrm{~g} / \mathrm{L}$. Then on the $15^{\text {th }}$ day, it was $1.10 \mathrm{~g} / \mathrm{L}$ and at the end of the experiment on the $18^{\text {th }}$ day was $1.23 \mathrm{~g} / \mathrm{L}$. That means with $0.30 \pm 0.05 \mathrm{~g} / \mathrm{L}$ of inoculum size the culture remained in the logarithmic phase of growth upto $18^{\text {th }}$ day. For inoculum size of $0.40 \pm 0.05 \mathrm{~g} / \mathrm{L}$ no lag phase was observed, the culture entered into the stationary phase on $12^{\text {th }}$ day. After which significant improvement in the growth was not observed. The maximum biomass produced till the $12^{\text {th }}$ day was only $1.10 \mathrm{~g} / \mathrm{L}$. Here, inoculum size of 0.30 $\pm 0.05 \mathrm{~g} / \mathrm{L}$ was found to be suitable over the other two inoculums.

In the case of $60 \mathrm{~L}$ PBR system in the optimized light intensity of 12000 Lux in laboratory conditions, inoculum size of $0.40 \pm 0.05$, and $0.50 \pm 0.05 \mathrm{~g} / \mathrm{L}$ showed the lag phase of 6 days. On $12^{\text {th }}$ day little increase in the biomass production was observed and then abrupt stationary phase was observed on $15^{\text {th }}$ day for these both inoculum sizes. Till the end of the experiment highest biomass obtained in both the inoculum sizes were 0.77 and $0.72 \mathrm{~g} / \mathrm{L}$ respectively. Whereas, when inoculum size of $0.30 \pm 0.05 \mathrm{~g} / \mathrm{L}$ was used, the progressive behavior in the growth pattern was observed. The lag phase observed was only of 3 days, but $\log$ phase continued till the end of the experiment i.e. $18^{\text {th }}$ day. The biomass obtained at the end of the experiment was $1.50 \mathrm{~g} / \mathrm{L}$, which was the highest biomass obtained if compared with the other two inoculums. Therefore, in indoor conditions for $60 \mathrm{~L}$ PBR system, the optimum inoculum would be $0.30 \pm 0.05 \mathrm{~g} / \mathrm{L}$ was accepted (Figure 12).

For the $250 \mathrm{~L}$ PBR system when inoculum size of $0.40 \pm 0.05 \mathrm{~g} / \mathrm{L}$ was utilized no lag phase was detected. From the beginning of the experiment the biomass was found to be consistently increasing till the end of the experiment. The maximum biomass obtained on $18^{\text {th }}$

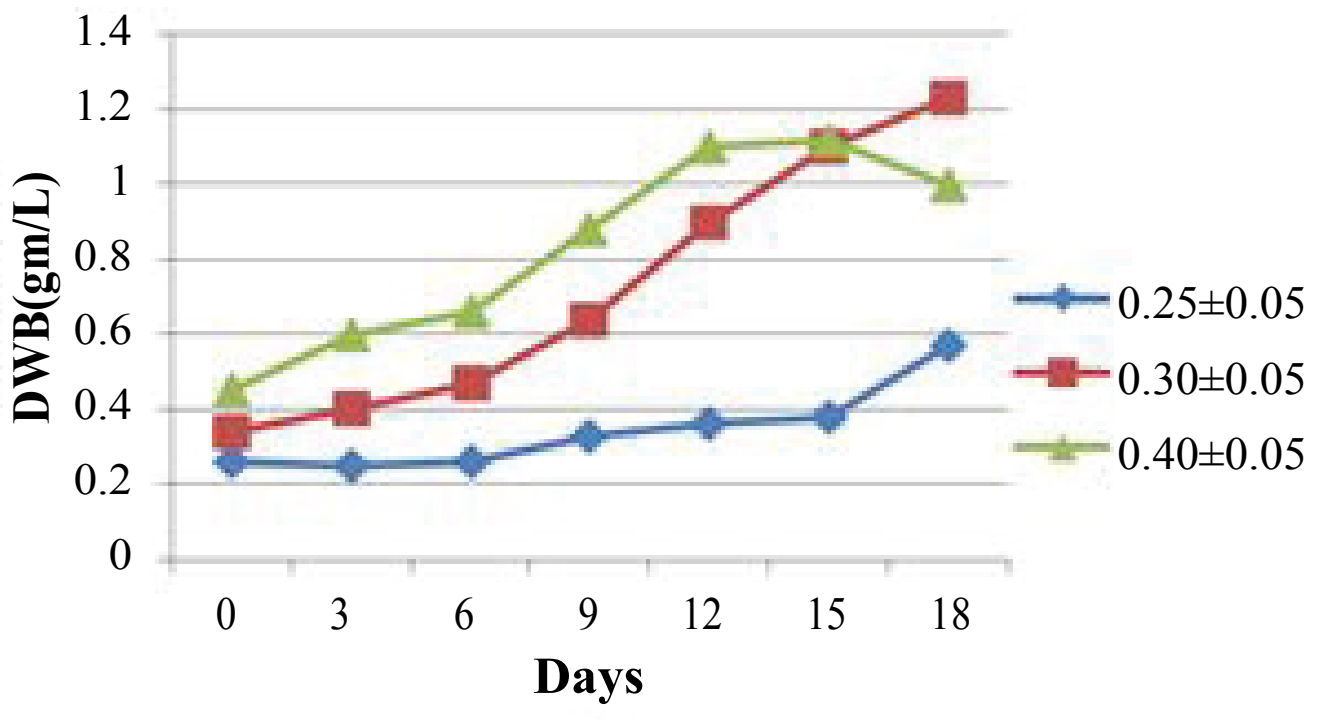

Figure 11: Inoculum size for $8 \mathrm{~L}$ flat plate PBR in laboratory condition.

\begin{tabular}{|c|c|c|c|c|c|c|c|c|c|c|}
\hline \multirow[t]{2}{*}{ S. No. } & \multirow{2}{*}{$\begin{array}{c}\text { No. of Days } \\
\text { PBR }\end{array}$} & \multicolumn{9}{|c|}{ Weight of dry Biomass (g/L) } \\
\hline & & $8 \mathrm{~L}$ & & & $60 \mathrm{~L}$ & & & $250 \mathrm{~L}$ & & \\
\hline & 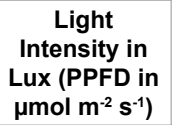 & $\begin{array}{c}2000 \pm 500(27 \\
\pm 6.75)\end{array}$ & $\begin{array}{l}4000 \pm 500 \\
(54 \pm 6.75)\end{array}$ & $\begin{array}{c}5000 \pm 500(67.5 \\
\pm 6.75)\end{array}$ & $\begin{array}{c}5000 \pm 500 \\
(67.5 \pm 6.75)\end{array}$ & $\begin{array}{c}8000 \pm 500 \\
(108 \pm 6.75)\end{array}$ & $\begin{array}{l}12000 \pm 500 \\
(162 \pm 6.75)\end{array}$ & $\begin{array}{l}12000 \pm 500 \\
(162 \pm 6.75)\end{array}$ & $\begin{array}{l}18000 \pm 500 \\
(243 \pm 6.75)\end{array}$ & $\begin{array}{l}24000 \pm 500 \\
(324 \pm 6.75)\end{array}$ \\
\hline 1 & 0 & 0.34 & 0.35 & 0.38 & 0.34 & 0.3 & 0.3 & 0.29 & 0.27 & 0.28 \\
\hline 2 & 5 & 0.37 & 0.57 & 0.43 & 0.47 & 0.35 & 0.53 & 0.3 & 0.34 & 0.64 \\
\hline 3 & 10 & 0.48 & 0.65 & 0.62 & 0.4 & 0.48 & 0.68 & 0.34 & 0.45 & 0.83 \\
\hline 4 & 15 & 0.9 & 1.2 & 0.63 & 0.5 & 0.7 & 0.93 & 0.35 & 0.58 & 0.98 \\
\hline 5 & 20 & 1.17 & 1.28 & 0.8 & 0.64 & 1 & 1.54 & 0.4 & 0.73 & 0.8 \\
\hline
\end{tabular}

Table 7: Screening of different light intensities for operation of $8 \mathrm{~L}, 60 \mathrm{~L}$ and $250 \mathrm{~L}$ capacity flat panel PBRs for algal cultivation. 
Citation: Magar CS, Deodhar MA (2018) Operational Strategies for Cost Effective Mass Cultivation of Halophilic Microalgal Strain Pseudanabaena limnetica in 1000 L Flat Panel Photobioreactor. J Pet Environ Biotechnol 9: 380. doi: 10.4172/2157-7463.1000380

Page 12 of 16

\begin{tabular}{|c|c|c|c|c|c|c|c|c|c|c|}
\hline \multirow{3}{*}{\multicolumn{2}{|c|}{\begin{tabular}{|c|c|} 
S. No. & $\begin{array}{c}\text { No. of } \\
\text { Days }\end{array}$ \\
PBR \\
$\begin{array}{c}\text { Inoculum } \\
\text { size }(\operatorname{gm} / \mathrm{L})\end{array}$ \\
\end{tabular}}} & \multicolumn{9}{|c|}{ Weight of dry Biomass (g/L) } \\
\hline & & \multicolumn{3}{|c|}{$8 \mathrm{~L}$} & \multicolumn{3}{|c|}{$60 \mathrm{~L}$} & \multicolumn{3}{|c|}{$250 \mathrm{~L}$} \\
\hline & & \multirow{2}{*}{$\begin{array}{c}\mathbf{0 . 2 5} \pm \mathbf{0 . 0 5} \\
0.26\end{array}$} & \multirow{2}{*}{$\begin{array}{c}\mathbf{0 . 3 0} \pm \mathbf{0 . 0 5} \\
0.34\end{array}$} & \multirow{2}{*}{$\begin{array}{c}\mathbf{0 . 4 0} \pm \mathbf{0 . 0 5} \\
0.45\end{array}$} & \multirow{2}{*}{$\begin{array}{c}\mathbf{0 . 3 0} \pm \mathbf{0 . 0 5} \\
0.30\end{array}$} & \multirow{2}{*}{$\begin{array}{c}\mathbf{0 . 4 0} \pm \mathbf{0 . 0 5} \\
0.40\end{array}$} & \multirow{2}{*}{$\begin{array}{c}\mathbf{0 . 5 0} \pm \mathbf{0 . 0 5} \\
0.45\end{array}$} & \multirow{2}{*}{$\begin{array}{c}\mathbf{0 . 4 0} \pm \mathbf{0 . 0 5} \\
0.42\end{array}$} & \multirow{2}{*}{$\begin{array}{c}\mathbf{0 . 5 0} \pm \mathbf{0 . 0 5} \\
0.50\end{array}$} & \multirow{2}{*}{$\begin{array}{c}0.60 \pm 0.05 \\
0.55\end{array}$} \\
\hline 1 & 0 & & & & & & & & & \\
\hline 2 & 3 & 0.25 & 0.40 & 0.60 & 0.44 & 0.45 & 0.47 & 0.57 & 0.64 & 0.76 \\
\hline 3 & 6 & 0.26 & 0.47 & 0.66 & 0.62 & 0.54 & 0.5 & 0.70 & 0.83 & 0.92 \\
\hline 4 & 9 & 0.33 & 0.64 & 0.88 & 0.79 & 0.68 & 0.64 & 0.81 & 0.95 & 1.10 \\
\hline 5 & 12 & 0.36 & 0.90 & 1.10 & 0.98 & 0.78 & 0.71 & 0.89 & 1.1 & 1.10 \\
\hline 6 & 15 & 0.38 & 1.10 & 1.12 & 1.23 & 0.80 & 0.76 & 1.0 & 1.18 & 1.12 \\
\hline 7 & 18 & 0.57 & 1.23 & 1.0 & 1.50 & 0.77 & 0.72 & 1.15 & 1.25 & 1.0 \\
\hline
\end{tabular}

Table 8: Determination of optimum inoculum size for operation of $8 \mathrm{~L}, 60 \mathrm{~L}$ and $250 \mathrm{~L}$ capacity flat panel PBRs for algal cultivation in laboratory condition.

\begin{tabular}{|c|c|c|c|c|}
\hline \multirow{2}{*}{ S. No. } & Env. Condition & \multicolumn{2}{|c|}{ Indoor } & \multicolumn{2}{|c|}{ Outdoor } \\
\cline { 2 - 5 } & PBR & Optimum inoculum size (g/L) & $\begin{array}{c}\text { Maximum biomass } \\
\text { produced (g/L) }\end{array}$ & $\begin{array}{c}\text { Optimum inoculum size (g/L) } \\
\text { Maximum biomass produced } \\
\text { (g/L) }\end{array}$ \\
\hline 1. & $8 \mathrm{~L}$ & $0.35 \pm 0.05$ & 1.23 & $0.25 \pm 0.05$ \\
\hline 2. & $60 \mathrm{~L}$ & $0.30 \pm 0.05$ & 1.50 & $0.35 \pm 0.05$ \\
\hline 3. & $250 \mathrm{~L}$ & $0.50 \pm 0.05$ & 1.25 & $0.35 \pm 0.05$ \\
\hline
\end{tabular}

Table 9: Effect of environmental conditions on Inoculum size required and maximum biomass production of $P$. limnetica in $8 \mathrm{~L}, 60 \mathrm{~L}$ and $250 \mathrm{~L}$ flat panel PBRs.

\begin{tabular}{|c|c|c|c|c|c|c|c|c|c|c|}
\hline \multirow{2}{*}{ S. No. } & \multirow{2}{*}{ PBR } & \multicolumn{3}{|c|}{ Electricity Consumption (KW/Day) } & \multicolumn{2}{|c|}{$\begin{array}{l}\text { Cost of Electricity on Total } \\
\text { Electricity Consumption }\end{array}$} & \multirow{2}{*}{$\begin{array}{l}\text { B. Cost of } \\
\text { medium (Rs.) }\end{array}$} & \multirow{2}{*}{$\begin{array}{l}\text { Total cost of PBR } \\
\text { operation for } 18 \\
\text { days batch }(A+B) \\
\text { (Rs.) }\end{array}$} & \multirow{2}{*}{$\begin{array}{l}\text { Total Biomass } \\
\text { produced at } \\
\text { end of batch } \\
\text { of } 18 \text { days } \\
(\mathrm{gm})\end{array}$} & \multirow{2}{*}{$\begin{array}{c}\text { Rs./Kg of } \\
\text { dry biomass }\end{array}$} \\
\hline & & $\begin{array}{c}\text { For Pneumatic } \\
\text { agitation }\end{array}$ & $\begin{array}{l}\text { For Light } \\
\text { exposure }\end{array}$ & $\begin{array}{c}\text { Total E } \\
\text { consumption }\end{array}$ & Rs./Day & $\begin{array}{c}\text { A. Rs. Per } \\
\text { Batch of } 18 \\
\text { Days }\end{array}$ & & & & \\
\hline 1 & $8 \mathrm{~L}$ & 0.12 & 1.15 & 1.27 & 3.899 & 70.182 & 7.95 & 78.132 & 10.64 & $7940.24 /-$ \\
\hline 2 & $60 \mathrm{~L}$ & 0.24 & 3.456 & 3.69 & 25.13 & 452.34 & 59.66 & 512.0 & 90.0 & $5688.89 /-$ \\
\hline 3 & $250 \mathrm{~L}$ & 4.416 & 11.520 & 15.93 & 155.48 & 2798.64 & 248.58 & 3047.22 & 312.5 & 9751.10/- \\
\hline
\end{tabular}

Table 10: Total cost estimation for operation of different flat panel PBRs in indoor conditions.

\begin{tabular}{|c|c|c|c|c|c|c|c|c|}
\hline \multirow{2}{*}{ Sr. No. } & \multirow{2}{*}{ PBR } & \multirow{2}{*}{$\begin{array}{c}\text { Electricity } \\
\text { Consumption (KW/ } \\
\text { Day) }\end{array}$} & \multicolumn{2}{|c|}{$\begin{array}{l}\text { Cost of Electricity on Total } \\
\text { Electricity Consumption }\end{array}$} & \multirow{2}{*}{$\begin{array}{c}\text { B. Cost of } \\
\text { medium (Rs.) }\end{array}$} & \multirow{2}{*}{$\begin{array}{c}\text { Total cost of } \\
\text { PBR operation } \\
\text { for } 18 \text { days } \\
\text { batch }(A+B) \\
\text { (Rs.) }\end{array}$} & \multirow{2}{*}{$\begin{array}{l}\text { Total Biomass } \\
\text { produced at end of } \\
\text { batch of } 18 \text { days } \\
(\mathrm{gm})\end{array}$} & \multirow{2}{*}{$\begin{array}{l}\text { Rs./Kg of dry } \\
\text { biomass }\end{array}$} \\
\hline & & & Rs./Day & $\begin{array}{l}\text { A. Rs. Per Batch } \\
\text { of } 18 \text { Days }\end{array}$ & & & & \\
\hline 1 & $8 \mathrm{~L}$ & 0.12 & 0.3684 & 6.6312 & 7.95 & 14.5812 & 14.4 & $1012.58 /-$ \\
\hline 2 & $60 \mathrm{~L}$ & 0.24 & 0.7368 & 13.2624 & 59.66 & 72.9224 & 94.2 & $774.123 /-$ \\
\hline 3 & $250 \mathrm{~L}$ & 4.416 & 30.07 & 541.26 & 248.58 & 789.84 & 250.0 & 3159.36/- \\
\hline
\end{tabular}

Table 11: Total cost estimation for operation of different flat panel PBRs in outdoor conditions.

day was $1.15 \mathrm{~g} / \mathrm{L}$. When inoculum size of $0.50 \pm 0.05 \mathrm{~g} / \mathrm{L}$ was utilized the no lag phase was observed. The biomass consistently grew and at the end of the experiment on the $18^{\text {th }}$ day, the maximum biomass was $1.25 \mathrm{~g} / \mathrm{L}$. When higher inoculum was utilized about $0.60 \pm 0.05 \mathrm{~g} / \mathrm{L}$ the early stationary phase was detected. After an initial 1 to 2 days growth period, the biomass obtained found to be drastically increased on $3^{\text {rd }}$ and $6^{\text {th }}$ day i.e. $0.76 \mathrm{~g} / \mathrm{L}$ and $0.92 \mathrm{~g} / \mathrm{L}$ respectively. On the $9^{\text {th }}$ day, the biomass obtained was $1.1 \mathrm{~g} / \mathrm{L}$ which remained constant till the end of the experiment. Therefore to operate $250 \mathrm{~L}$ flat panel PBR system in indoor condition inoculum size of $0.50 \pm 0.05 \mathrm{~g} / \mathrm{L}$ was found to be optimum, in which culture continuously stays in growth or log phase (Figure 13).

Kenekar et al. [28], have studied the effect of inoculum size on a growth of Geitlerinema sulphureum in $25 \mathrm{~L}$ capacity tubular photobioreactor. In this PBR when the lower inoculum $(0.25 \mathrm{~g} / \mathrm{L})$ was utilized the culture was found to be stuck to the wall of the tube after overnight light exposure. When inoculum size of $0.35 \mathrm{~g} / \mathrm{L}$ was utilized the lag phase was not observed, but the significant growth was also not achieved and the maximum biomass yield obtained was $0.615 \mathrm{~g} / \mathrm{L}$. When inoculum size was increased to $0.45 \mathrm{~g} / \mathrm{L}$ the maximum biomass was achieved i.e., $0.802 \mathrm{~g} / \mathrm{L}$ till $8^{\text {th }}$ day. Beyond this further increase in the inoculum size to $0.55 \mathrm{~g} / \mathrm{L}$ gave highest biomass of $0.789 \mathrm{~g} / \mathrm{L}$ within 5 days of the growth and beyond this reduction in the growth was seen. From these results they have inferred that intermediatery inoculum density $(0.45 \mathrm{~g} / \mathrm{L})$ is ideal to maximize the biomass productivity.

Chen et al. [8] have depicted that the higher the inoculum size, maximum will be the final biomass produced in case of Nannochlorpsis $s p$. They have studied three different ranges of initial population densities (IPD), that is Low IPD (0.11-0.33 g/L), Moderate IPD (0.98$2.63 \mathrm{~g} / \mathrm{L})$, and High IPD (6.23-9.09 g/L) and their effect on biomass as well as lipid production. In the results, it was found that the lower IPD produces very low biomass, whereas high IPD produced high biomass 


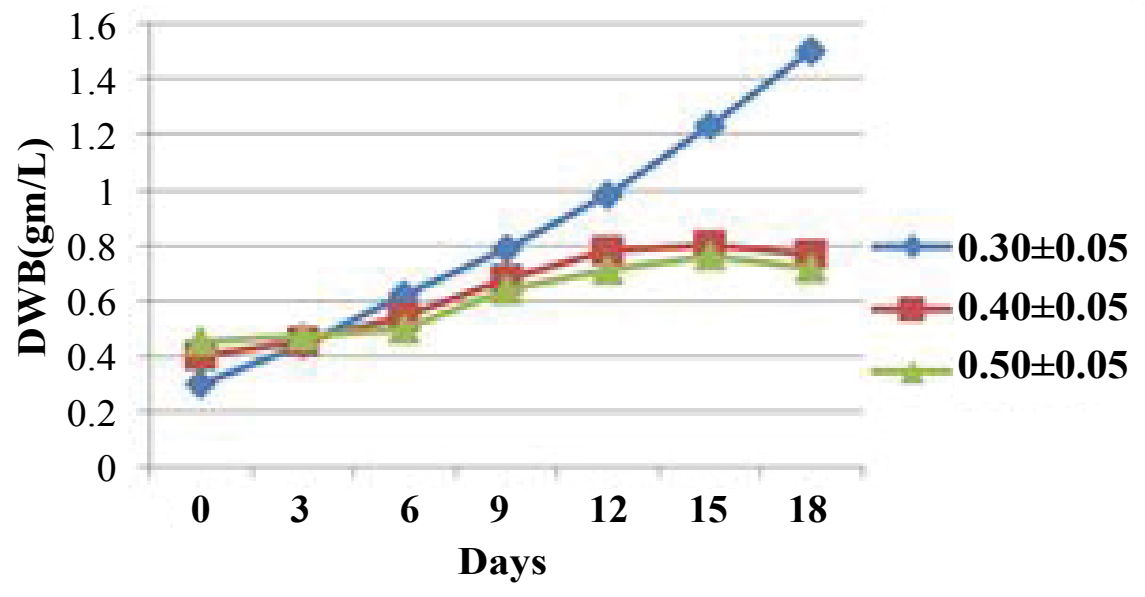

Figure 12: Inoculum size for $60 \mathrm{~L}$ flat plate PBR in laboratory condition.

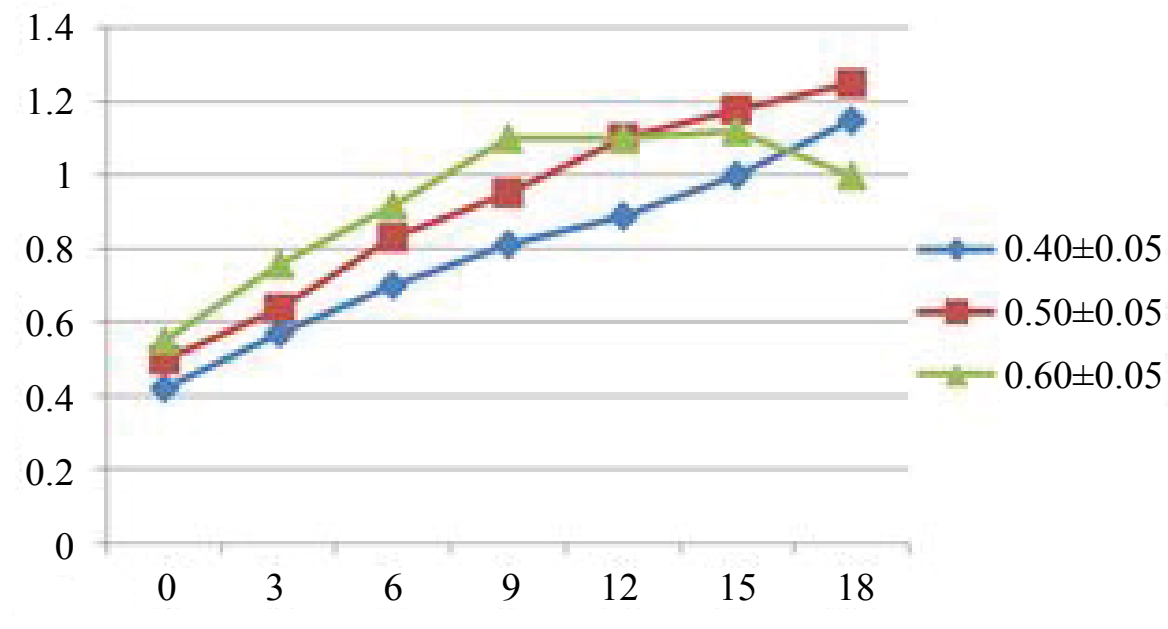

Figure 13: Inoculum size for $250 \mathrm{~L}$ flat plate PBR in laboratory condition.

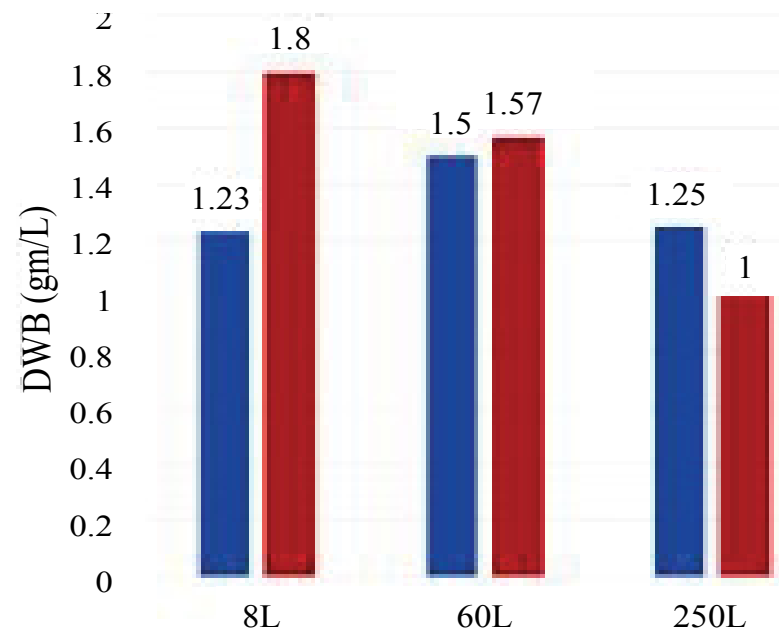

- Maximum biomass produced in indoor condition $(\mathrm{gm} / \mathrm{L})$

- Maximum biomass produced in outdoor condition $(\mathrm{gm} / \mathrm{L})$

Flat Panel PBR

Figure 14: Effect of indoor (laboratory) conditions and outdoor conditions on biomass productivity in $8 \mathrm{~L}, 60 \mathrm{~L}$ and $250 \mathrm{~L}$ flat panel PBR. 


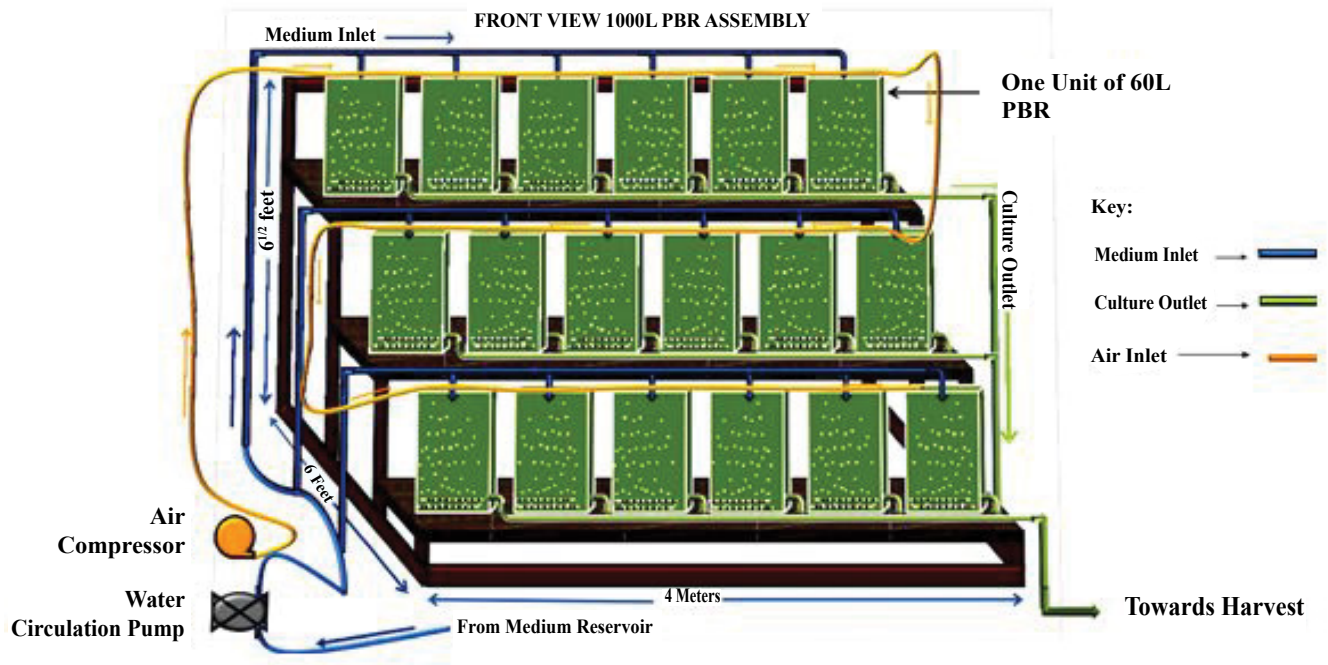

Figure 15: Schematic diagram of $1000 \mathrm{~L}$ capacity flat panel PBRs assembly.

but in both the cases biomass productivity was found to be least. When moderate IPD was utilized highest biomass productivity was achieved and when compared with nitrogen consumption in all the three IPD's the maximum nitrogen consumption was observed with this moderate IPD. This finding support that, the moderate inoculum size helped to achieve an optimum growth along with maximum nitrogen utilization and biomass productivity which are the signs of better growth.

As discussed in 3.3 increases in size of the PBR is associated with the increase in breadth of the PBR. For $60 \mathrm{~L}$ capacity PBR the breadth in $20 \mathrm{~cm}$ and for $250 \mathrm{~L} \mathrm{PBR}$ it is $28 \mathrm{~cm}$. For $60 \mathrm{~L} \mathrm{PBR}$ the optimum light intensity required was $12,000 \mathrm{Lux}$ and for $250 \mathrm{~L}$ it was $24,000 \mathrm{Lux}$, also the reactor was failing to produce biomass comparable to $60 \mathrm{~L} \mathrm{PBR}$. To overcome the high cost required for the high irradiance the PBR was operated in outdoor condition. In summer season in Mumbai, Maharashtra the light intensity goes beyond 100,000 Lux. Our salt pan isolate Pseudanbaena limnetica was well tolerant to such high light intensity.

As quoted by Qiang et al. [24] at such high light irradiance, the requirement of optimal culture density increases with increasing light intensity. Hence, it was decided to find out optimal inoculum density in outdoor conditions for $8 \mathrm{~L}, 60 \mathrm{~L}$ and $250 \mathrm{~L}$ PBR. But our observations were contradictory to the observations of Qiang et al. [24]. For all the sizes of PBRs the optimum inoculum required in outdoor conditions was less than the inoculum required in indoor conditions.

For $8 \mathrm{~L}$ in indoor conditions the inoculum required was $0.30 \pm 0.05$ $\mathrm{g} / \mathrm{L}$, whereas for outdoor conditions the optimum inoculum density was $0.25 \pm 0.05 \mathrm{~g} / \mathrm{L}$. For indoor operation of $60 \mathrm{~L} \mathrm{PBR}$, the optimum inoculum required was $0.30 \pm 0.05 \mathrm{~g} / \mathrm{L}$, whereas in outdoor conditions inoculum required was $0.35 \pm 0.05 \mathrm{~g} / \mathrm{L}$ which was a same quantity in both the conditions. For $250 \mathrm{~L}$ PBR for indoor condition the inoculum required was very high i.e. $0.50 \pm 0.05 \mathrm{~g} / \mathrm{L}$, whereas for outdoor conditions $0.35 \pm 0.05 \mathrm{~g} / \mathrm{L}$ of inoculum was sufficient (Table 9).

When the comparison for inoculums size required and maximum biomass produced by each PBR system in indoor and outdoor environmental conditions was carried out, it was observed that less inoculums size was required for outdoor operation as compared to indoor operations. This would reduce the cost of inoculum development when industrial scale cultivation is considered.
In Table 9, the results obtained from indoor and outdoor studies for inoculum size have been compiled. For $8 \mathrm{~L}$ PBR the optimum inoculum of $0.35 \pm 0.05 \mathrm{~g} / \mathrm{L}$ during indoor operation produced maximum biomass yield of $1.23 \mathrm{~g} / \mathrm{L}$. Whereas in outdoor operation optimum inoculum of $0.25 \pm 0.05 \mathrm{~g} / \mathrm{L}$ yielded maximum biomass of 1.8 $\mathrm{g} / \mathrm{L}$, which is a significant improvement found in biomass production (Figure 14). In case of $60 \mathrm{~L} \mathrm{PBR}$, in indoor operation $0.30 \pm 0.05 \mathrm{~g} / \mathrm{L}$ of inoculum size produced $1.5 \mathrm{~g} / \mathrm{L}$ of highest biomass which was lesser than the biomass obtained in outdoor operation i.e. $1.57 \mathrm{~g} / \mathrm{L}$ with an optimum inoculum size of $0.35 \pm 0.05 \mathrm{~g} / \mathrm{L}$. Here optimum inoculum size was almost similar in both the environments but biomass yield was higher in outdoor conditions than indoor. For $250 \mathrm{~L} \mathrm{PBR}$ in indoor operation optimum inoculum required was $0.50 \pm 0.05 \mathrm{~g} / \mathrm{L}$ which was too high than the inoculum required in outdoor operation i.e. only 0.35 $\pm 0.05 \mathrm{~g} / \mathrm{L}$. The biomass produced indoor operation was $1.25 \mathrm{~g} / \mathrm{L}$ and in outdoor operation it was $1 \mathrm{~g} / \mathrm{L}$.

\section{Cost estimation for operation of PBRs in indoor and outdoor conditions}

Cost of PBRs has a major influence on production cost for large scale biomass. The reduction of the PBR cost dramatically decreases the biomass production cost. The ways to reduce cost depends on the type of algal strain, the type of PBRs, and the production technology of the biomass. The major cost factors are irradiation conditions, mixing, and photosynthetic efficiency of the algae, the medium and carbondioxide costs [29]. Further communication deals with the estimation of operation cost of each PBR system.

While doing the cost estimation for operation of PBRs in indoor conditions, the major expenditure was found to be incurred for electricity and nutrient components or chemicals used for medium preparation. The electricity was majorly consumed for the pneumatic agitation and light illumination. The total electricity consumption per day was estimated (Table 10). It was found that 1.27, 3.69 and $15.93 \mathrm{KW} /$ day of electricity was required for the operation of $8 \mathrm{~L}, 60 \mathrm{~L}$ and $250 \mathrm{~L}$ flat panel PBR respectively. In a batch mode of operation, one batch estimated was of around 18 days, accordingly electricity consumption for 18 days of period was considered. Per liter medium cost was 
estimated and it was found to be 0.99 INR. The total cost of operation of PBR for 18 days batch was calculated and for $8 \mathrm{~L} \mathrm{PBR}$ it was 78.132 INR, 60 L PBR 512.0 INR and for 250 L PBR the operating cost was 3047.22 INR. Also total biomass (dry weight) produced in one batch from each PBR system was estimated to be $10.64 \mathrm{~g}$ in $8 \mathrm{~L}$ PBR, $90 \mathrm{~g}$ in 60 L PBR and $312.5 \mathrm{~g}$ in $250 \mathrm{~L}$ PBR. Ultimately how much expenditure will be incurred to produce one $\mathrm{kg}$ of dry biomass from each system have been calculated. The highest expenditure will incur for the operation of 250 L PBR system i.e. 9751.10 INR. Then for 8 L PBR 7940.24 INR will be needed for the production of one kg of dry biomass. The lowest expenditure calculated was found to be for the $60 \mathrm{~L}$ PBR system i.e., 5688.89 INR per kg of dry biomass. This increase or decrease in the cost was found to be directly proportional to the biomass productivity of each system, higher the productivity lesser will be the cost of per $\mathrm{kg}$ biomass production. Here in comparison with $8 \mathrm{~L}$ and $250 \mathrm{~L}$ flat panel systems, $60 \mathrm{~L} \mathrm{PBR}$ was found to be less expensive and can consider in further experimental studies.

After estimation of the costing for an indoor operation of the each PBR system, these PBRs were operated in outdoor natural light conditions. The maximum sunlight irradiation of $\sim 65,000-85,000 \mathrm{Lux}$ light intensity was achieved, to which culture was exposed in respective PBR. The inoculum sizes for the operation of PBRs were optimized and maximum yield of the biomass per batch was estimated. As previously explained here also for estimation of operational cost of each PBR, electricity consumption for pneumatic agitation and medium cost was considered (Table 11). Here for outdoor condition major cost that was required for artificial light exposure in indoor condition was curtailed down. The total electricity consumption for only pneumatic agitation in KW per day was calculated to be $0.12,0.24$ and 4.416 for $8 \mathrm{~L}, 60 \mathrm{~L}$ and 250 L PBR respectively. Cost in INR for operation of each PBR every day was calculated from per day total electricity consumption units. Rs. 0.3684/-, Rs. 0.7368/- and Rs. 30.07/- was the estimated cost in INR, for every day operation of $8 \mathrm{~L}, 60 \mathrm{~L}$, and $250 \mathrm{~L}$ respectively. One batch was of 18 days, so accordingly cost of 18 days operation was determined to be Rs. 6.6312/-, Rs. 13.2624/- and Rs. 541.26/- for $8 \mathrm{~L}, 60 \mathrm{~L}$ and 250 $\mathrm{L}$ respectively. Additionally cost of the medium was added in batch operation and final cost per batch was calculated for each PBR, which was found to be INR. 14.5812/- for 8 L PBR, 72.9224/- for 60 L PBR and 789.84/- for $250 \mathrm{~L}$ PBR. The total biomass produced per batch by $8 \mathrm{~L}$ PBR was $14.4 \mathrm{~g}$, by $60 \mathrm{~L}$ was $94.2 \mathrm{~g}$ and by $250 \mathrm{~L}$ PBR was $250 \mathrm{~g}$. Finally for production of $1 \mathrm{~kg}$ of dry algal biomass the operation cost of each system was elucidated, and it was found for 8 L PBR INR.1012.58/-, for 60 L system INR. 774.123/- and for 250 L PBR INR. 3159.36/- will be the operation cost behind per kg dry weight of the algal biomass.

Indoor and outdoor operation cost for each PBR system was compared to obtain $1 \mathrm{~kg}$ dry biomass. This cost was found to be less in outdoor environmental condition, as the major cost of artificial light exposure required in indoor condition was reduced. For $8 \mathrm{~L}$ system as explained earlier indoor operation cost was 7940.24 rupees which was reduced by 7 to 8 times in outdoor conditions i.e., only 1012.58 rupees. For $60 \mathrm{~L}$ PBR indoor operation cost was 5688.89 rupees which was reduced to 774.123 rupees in outdoor conditions, which was again 7 times lesser than its indoor operation cost. In case of $250 \mathrm{~L}$ PBR when operated in indoor conditions the cost was 9751.10 rupees which was reduced by 3 times to 3159.36 rupees when operated in outdoor environment. When comparative study of each PBR system was carried out, the maximum yield of the biomass along with minimum operation cost per batch was found for $60 \mathrm{~L}$ flat panel PBR. When outdoor operation cost of $60 \mathrm{~L}$ PBR was compared with the costing estimated by Slade et al. [30], it was found exactly similar to their estimation. By utilizing cost modeling techniques, they have postulated the base case production cost of algal biomass in the idealized tubular PBR system is $\sim 9 € \mathrm{~kg}^{-1}$ to $10 € \mathrm{~kg}^{-1}\left(\sim 741.25\right.$ INR. $\mathrm{kg}^{-1}$ to $\left.823.61 \mathrm{INR}^{\mathrm{k}} \mathrm{kg}^{-1}\right)$ and the projected case cost is $\sim 3.8 € \mathrm{~kg}^{-1}\left(\sim 312.97\right.$ INR. $\left.\mathrm{kg}^{-1}\right)$.

Park et al. [31] have explained the utilization of marine resources like seawater for mass cultivation and by-products recovered from the biomass produced could lead to the generation of extra revenue, which will help to sustain this technology. Therefore in our study from the beginning we have stressed upon the use of seawater as a medium for marine halophilic microalgal strain cultivation.

\section{Construction of $1000 \mathrm{~L}$ capacity flat panel PBR assembly}

To construct $1000 \mathrm{~L} \mathrm{PBR}$, total 18 units of $60 \mathrm{~L}$ flat panel PBR were arranged in 3 rows, each containing 6 units (Figure 15). The PBRs were arranged on metallic stand of $6 \frac{1}{2}$ feet height. It had 3 platforms, the length of each platform is 13.33 feet and breadth is 2 feet. The distance or the height between 2 platforms is $2 \frac{1}{2}$ feet. The pipe inlet for dispensing medium and outlets for collecting the biomass are provided. Each $60 \mathrm{~L}$ PBR unit is provided along with a pair of spargers at the bottom of the PBR. The PBR is operated on terrace at natural illumination.

\section{Conclusion}

Three different flat panel PBR systems had been developed and their operation strategies successfully optimized. This optimization experiments involved the screening of different air flow rates, sparger pore size, light intensities, inoculums size, etc. Out of these parameters air flow rate and sparger pore size were related to the optimization of pneumatic agitation system. The pneumatic agitation system has been critically judged and its effect on superficial gas velocity, sparger velocity, Reynolds no. etc. has been studied. Optimum light intensity required for maximum algal growth in each PBR system has been screened. After optimization of all the physical parameters the inoculums size for operation of each PBR in indoor culture conditions have been determined. All the three PBR systems were operated in outdoor open environment for estimating their ability to withstand in actual environmental conditions without hampering the growth of selected salt pan isolate of microalgae $P$. limnetica. The cost estimation of each PBR operation in indoor as well as outdoor conditions have been carried out and most cost effective PBR system of $60 \mathrm{~L}$ volume holding capacity had been shortlisted for construction of $1000 \mathrm{~L}$ PBR assembly.

\section{Conflicts of Interest}

The authors declare that the research was conducted in the absence of any commercial or financial relationships that could be constructed as a potential conflict of interest.

\section{Author Contributions}

All authors listed have made a substantial, direct and intellectual contribution to the work, and approved it for publication.

\section{Funding}

This research work was funded by Department of Biotechnology (DBT), Ministry of Science and Technology, Government of India, New Delhi, under grant agreement no. BT/PR12347/PBD/26/476/2015.

\section{Acknowledgments}

The authors acknowledge Department of Biotechnology (DBT), New Delhi for the support of this project under the call 'Mass Cultivation of Algae for Cost Effective Biofuel Production'. The grant agreement number was BT/PR12347/ $\mathrm{PBD} / 26 / 476 / 2015$

Authors are also thankful to Principal, Dr. B. B. Sharma and Kelkar Education 
Citation: Magar CS, Deodhar MA (2018) Operational Strategies for Cost Effective Mass Cultivation of Halophilic Microalgal Strain Pseudanabaena limnetica in 1000 L Flat Panel Photobioreactor. J Pet Environ Biotechnol 9: 380. doi: 10.4172/2157-7463.1000380

Trust of V. G. Vaze College Mulund East, Mumbai for their support to carry out this research work.

\section{References}

1. Razzak SA, Hossain MM, Lucky RA, Bassi AS, De lasa H (2013) Integrated $\mathrm{CO}_{2}$ capture wastewater treatment and biofuel production by microalgae culturing-A review. J Renew Sustain Energy 27: 622-653.

2. Jegathese SJP, Farid M (2014) Microalgae as a renewable source of energy: A niche opportunity. J Renew Energy 14: 1-10

3. Singh NK, Dhar DW (2011) Microalgae as second generation biofuel. A review. Agron Sustain Dev 31: 605-629.

4. Bahadar A, Khan MB (2013) Progress in energy from microalgae: A review. $J$ Renew Sustain Energy 27: 128-148.

5. Zeng X, Guo X, Su G, Danquah MK, Zhang S, et al. (2015) Bioprocess considerations for micro algal based wastewater treatment and biomass production. J Renew Sustain Energy 42: 1385-1392.

6. Ting H, Haifeng L, Shanshan M, Zhang Y, Zhidan L, et al. (2017) Progress in microalgae cultivation photo bioreactors and applications in wastewater treatment: A review. Int J Agric Biol Eng 10: 1-29.

7. Patrick L, Patrick S (1996) Manual on the production and use of live food for aquaculture. FAO Fisheries Technical Paper 361, University of Ghent, Ghent, Belgium.

8. Chen Y, Wang J, Liu T, Gao L (2012) Effects of initial population density (IPD) on growth and lipid composition of Nannochloropsis sp. J Appl Phycol 24: $1623-1627$.

9. Rippka R, Stanier R, Deruelles J, Herdman M, Waterbury JB (1979) Generic assignments strain histories and properties of pure cultures of cyanobacteria. J Microbiol 111: 1-61.

10. Guo X, Yao L, Huang Q (2015) Aeration and mass transfer optimization in a rectangular airlift loop photo bioreactor for the production of microalgae. Bioresour Technol 190: 189-195.

11. Nilesh C (2012) Optimization of vertical photo bioreactors. M.sc Thesis, Schoo of Engineering of the University of Dayton, USA.

12. Vega-Estrada J, Montes-Horcasitas MC, Dominguez-Bocanegra AR Canizares-Villanueva RO (2005) Haematococcus pluvialis cultivation in splitcylinder internal-loop airlift photo bioreactor under aeration conditions avoiding cell damage. Appl Microbiol Biotechnol 68: 31-35.

13. Miron AS, Garcia MC, Gomez AC, Camacho FG, Grima EM, et al. (2003) Shear stress tolerance and biochemical characterization of Phaeodactylum tricornutum in quasi steady-state continuous culture in outdoor photobioreactors. Biochem Eng J 16: 287-297.

14. Merchuk JC (1991) Shear effects on suspended cells. In: Bioreactor systems and effects, Advances in Biochemical Engineering Biotechnology. Springer Berlin.

15. Barbosa MJ, Albrecht M, Wijfels RH (2003) Hydrodynamic stress and lethal events in sparged microalgae cultures. Biotechnol Bioeng 83: 112-120.
16. Falinski KA, Michael TB, Chatham C, Charles L (2018) Response of Tisochrysis lutea [Prymnesiophycidae] to aeration conditions in a bench-scale photo bioreactor, J Appl Phycol 30: 2203 -2214.

17. Kulkarni AV, Roy SS, Joshi JB (2007) Pressure and flow distribution in pipe and ring spargers: Experimental measurements and CFD simulation. Chem Eng $J$ 133: $173-186$

18. Falinski KA (2009) Effects of different aeration conditions on /sochrysis galbana (T-ISO) ccmp 1324 in a bench-scale photo bioreactor, M.Sc Thesis, Graduate School of Cornell University, USA.

19. Silva HJ, Cortifas T, Ertola RJ (1987) Effect of hydrodynamic stress on Dunaliella growth. J Chem Technol Biotechnol 40: 41-49.

20. Suzuki T, Matsuo T, Ohtaguchi K, Koide K (1995) Gas-sparged bioreactors for CO fixation by Dunaliella tertiolecta. J Chem Technol Biotechnol 62: 351-358.

21. Pal SW, Singh NK, Azam K (2013) Evaluation of Relationship between Ligh Intensity (Lux) and Growth of Chaetoceros muelleri. J Oceanogr Mar Res 1: 3.

22. Qingshan H, Fuhua J, Lianzhou W, Chao Y (2017) Design of photo bioreactors for mass cultivation of photosynthetic organisms. Eng 3: 318-329.

23. De Vree Jeroen H, Rouke B, Marcel J, Barbosa Maria J, Wijffels Rene H (2015) Comparison of four outdoor pilot-scale photo bioreactors, Biotechnol Biofuel 8: 1-12.

24. Hu Q, Yair Z, Amos R (1998) Combined effects of light intensity, light-path and culture density on output rate of Spirulina platensis (Cyanobacteria). Eur J Phycol 33: 165-171.

25. Ning J, Amos R (1999) Effect of light-path length in outdoor flat plate reactors on output rate of cell mass and of EPA in Nannochloropsis sp. J Biotechnol 70 351-356.

26. Liang F, Xiaobin W, Yahong G, Zhengrong O, Liming L, et al. (2013) Growth rate and biomass productivity of Chlorella as affected by culture depth and cel density in an open circular photobioreactor. J Microbiol Biotechnol 23: 539-544.

27. Hu Q, Richmend A (1996) Productivity and photosynthetic efficiency of Spirulina platensis as affected by light intensity, algal density and rate of mixing in a flat plate photobioreactor. J Appl Phycol 8: 139-145.

28. Kenekar AA, Deodhar MA (2014) Operational strategies for lab scale horizontal tubular photobioreactor for mitigation of $\mathrm{CO}_{2}$ usig an indigenous thermophilic microalgal strain Geitlerinema sulphureum. J Pet Environ Biotechnol 5: 176.

29. Acien FG, Fernandez JM, Magan JJ, Molina E (2012) Production cost of a real microalgae production plant and strategies to reduce it. Biotechnol Adv 30: 1344-1353.

30. Slade R, Bauen A (2013) Micro-algae cultivation for biofuels: Cost, energy balance, environmental impacts and future prospects. Biomass Bioenergy 53 29-38.

31. Hanwool P, Choul-Gyun $L$ (2016) Theoretical calculations on the feasibility of microalgal biofuels: Utilization of marine resources could help realizing the potential of microalgae. Biotechnol J 11: 1461-1470. 